\title{
Design, Synthesis, Biological Evaluation and Inhibition Mechanism of 3-/4-Alkoxy Phenylethylidenethiosemicarbazides as New, Potent and Safe Tyrosinase Inhibitors
}

\author{
Senchuan Song, Yuliang Mai, Huahong Shi, Bing Liao*, and Fei Wang* \\ Guangdong Research Institute of Petrochemical and Fine Chemical Engineering, Guangdong Academy of Sciences; \\ Guangzhou 510665, P. R. China. \\ Received October 26, 2019; accepted January 22, 2020
}

Tyrosinase plays important roles in many different disease related processes, and the development of its inhibitors is particularly important in biotechnology. In this study, thirty-nine 3-/4-alkoxyphenylethylidenethiosemicarbazides were synthesized as novel tyrosinase inhibitors based on structure-based molecular design. Our experimental results demonstrated that thirty-one of them possess remarkable tyrosinase inhibitory activities with $\mathrm{IC}_{50}$ value below $1 \mu \mathrm{M}$, and $5 \mathrm{a}, 6 \mathrm{e}, 6 \mathrm{~g}$ and $6 \mathrm{t}$ did not display any toxicity to $293 \mathrm{~T}$ cell line at the concentration of $1000 \mu \mathrm{mol} / \mathrm{L}$. According to the inhibitory activities, several compounds were selected for detail investigation on the structure-activity relationships (SARs), mechanisms of enzyme inhibition, inhibitory kinetics and cytotoxicity. In particular, the interaction between the selected inhibitors and the active center of tyrosinase was considered and discussed in detail based on their structural characteristics. Taken together, the results presented here demonstrated that the newly designed compounds are promising candidates for the treatment of tyrosinase-related disorders and further development of them may have significant contribution in biomedical science.

Key words thiosemicarbazone; tyrosinase inhibitor; structure-activity relationship; inhibition mechanism; inhibitory kinetics; cytotoxicity

\section{Introduction}

Tyrosinase (EC 1.14.18.1) is a multifunctional oxygenase widely distributed in nature, structurally belonging to the type-3 copper protein family. ${ }^{1-3)}$ It catalyzes the hydroxylation of L-tyrosine to L-3,4-dihydroxyphenylalanine (L-DOPA) and the oxidation of L-DOPA to dopaquinone. Dopaquinone is highly reactive and can be oxidized spontaneously to form melanin, which is responsible for the color of mammal-skin and -hair. ${ }^{4-8)}$ Recent studies showed that tyrosinase is involved in the molting process of insects ${ }^{9-12)}$ and the browning of fruits and vegetables. ${ }^{13-15)}$ More importantly, tyrosinase also plays important roles in many human diseases, including Parkinson's and other neurodegenerative diseases, ${ }^{16-18}$ ) and the formation of some dermatological disorders, such as hyperpigmentation, freckles, melasma, ephelide, and senile lentigines. ${ }^{19-21)}$ Therefore, tyrosinase inhibitors have become increasingly important in food industry, agriculture, cosmetics, and biomedical science.

Over the past decade, many efforts have been spent on searching for new and effective tyrosinase inhibitors, and a tremendously large number of naturally occurring and synthetic tyrosinase inhibitors have been reported. ${ }^{22-35)}$ Unfortunately, only few of them can be used in practice due to the lack of their individual activities or safety concerns. Therefore, more efforts are urgently needed to search and develop new, potent and safe tyrosinase inhibitors with improved therapeutic profiles. Among those reported tyrosinase inhibitors, thiosemicarbazide derivatives occupied a particularly prominent position ${ }^{36-56)}$ because of their remarkable inhibitory activities against tyrosinase. However, the structural modification of 1-(1-phenyl-ethylidene)thiosemicarbazides for functional optimization has not been reported.

Although the crystallographic structure of tyrosinase revealed that there is a lipophilic long-narrow gorge near to the binuclear copper active center, ${ }^{57-59)}$ which may be related the enzyme inhibitory mechanism, and the specific mode of the interaction between the thiosemicarbazone molecule with these two copper ions in the active center of tyrosinase has been reported, ${ }^{45}$ the detailed binding process of inhibitors to these two copper ions is still not known. According to the information provided in-house ${ }^{51-53)}$ (Fig. 1) and from other groups, ${ }^{42,54-56)}$ thirty-nine novel 3-/4-alkoxy substituted phenylethylidenethiosemicarbazide derivatives bearing both a thiosemicarbazone moiety and a proper alkoxy lipophilic group were designed and synthesized, and their inhibitory effects on mushroom tyrosinase were evaluated. Furthermore, the structure-activity relationships (SARs) were discussed, and the inhibition mechanisms, the inhibitory kinetics and the cytotoxicity of selected compounds were investigated in the present study. Based on the results, the interaction process between the thiosemicarbazone molecule of the inhibitors and the two copper ions in active center of tyrosinase was speculated. We hope that this study can lead to the development of highly potent and safe pharmacological agents for the treatment of tyrosinase-related disorders.

\section{Results and Discussion}

Synthesis The synthesis of $\mathbf{5 a}-\mathbf{m}, \mathbf{6 a}-\mathbf{v}, \mathbf{1 1}$ and $\mathbf{1 2 a}-\mathbf{c}$ was summarized in Chart 1, and the structures of the corresponding alkoxy substituent at the phenyl ring were given in Table 1. Briefly, the alkoxy-acetophenones $3 \mathbf{a}-\mathbf{m}, \mathbf{4 a}-\mathbf{n}, \mathbf{4} \mathbf{p}-\mathbf{v}$ and the alkoxy-benzaldehydes $\mathbf{9}, \mathbf{1 0 a}-\mathbf{c}$ were synthesized through 


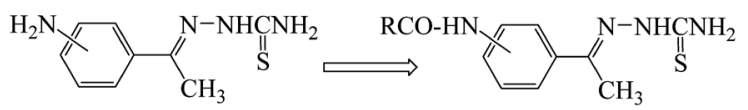

Previous work 1, Ref. 52, Eur. J. Med. Chem., 93, 255 (2015)
1) The introduction of proper hydrophobicsubstituent can obviously enhance the inhibitory activity

2) The position (3- or 4-) of amide group can

obviously effect the inhibitoryl activity

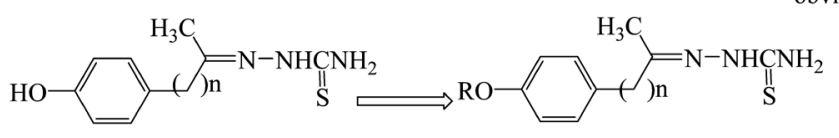

Introduction of $\mathrm{R}$ can enhance the inhibitory activity and $\mathrm{CH}_{3} \mathrm{CO}$ is the best substituent

Previous work 2 , Ref. 51, Bioorg. Med. Chem., 23, 924 (2015)

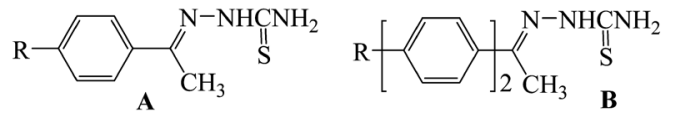

Previous work 3, Ref. 53, Eur. J. Med. Chem., 139, 815 (2017).

1) For $\mathbf{A}, R$ is an alkyl or an alkyl with hydrophilic ester group at the top, they all exhibited higher inhibitory activity

2) For $\mathbf{B}$, when $R$ is an alkoxy, they showed weaker inhibitory activity; when $\mathrm{R}$ is $-\mathrm{CH}_{2} \mathrm{CO}_{2} \mathrm{R}$, they showed higher inhibitory activity

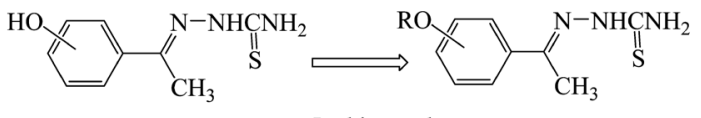

1) Investigate $S A R s$ and sceen out the best $R$ group 2) Further explore the mechanism of phenylethylidenethiosemicarbazide inhibitors In this work

Fig. 1. Comparison of the Content in Previous Work and in This Work and the Aim of This Work

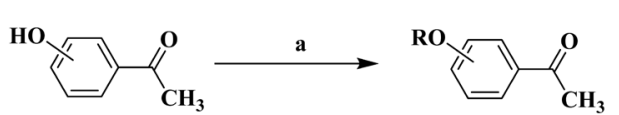

1, 1-(3-Hydroxyphenyl)ethanone 3a-m, 1-(3-Alkoxyphenyl)ethanone 2,1-(4-Hydroxyphenyl)ethanone 4a-n, 4p-v, 1-(4-Alkoxyphenyl)ethanone

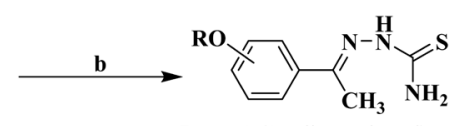

5a-m, 1-(3-Alkoxyphenyl)ethylidenethiosemicarbazide 6a-n, 6p-v, 1-(4-Alkoxyphenyl)ethylidenethiosemicarbazide

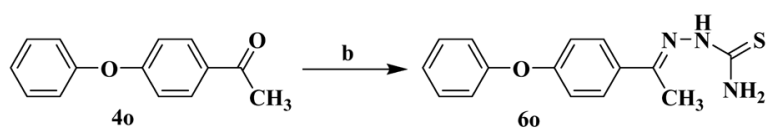

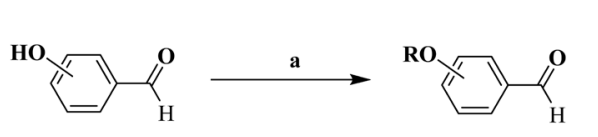

7, 3-Hydroxybenzaldehyde 8, 4-Hydroxybenzaldehydee
9,3-(3-Hydroxypropoxy)benzaldehyde 10a-c, 4-Alkoxybenzaldehyde

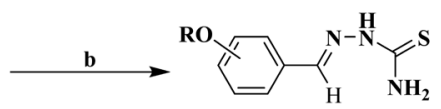

11, 2-(4-(3-Hydroxypropoxy)benzylidene)hydrazine-1-carbothioamide 12a-c, 2-(3-Alkoxybenzylidene)hydrazine-1carbothioamide

Reagents and reaction conditions: (a) $\mathrm{RX}\left(\mathrm{X}=\mathrm{Br}\right.$ or I), $\mathrm{K}_{2} \mathrm{CO}_{3}$, anhydrous acetone, $\mathrm{RT}, 4-8 \mathrm{~h}$; (b) thiosemicarbazide, anhydrous ethanol, acetic acid, $50-80^{\circ} \mathrm{C}, 3 \mathrm{~h}$.

Chart 1. Synthesis of 1-(Alkoxyphenyl)ethylidenethiosemicarbazide Compounds (5a-m and 6a-v) and 2-Alkoxybenzylidenehydrazine-1-carbothioamide Compounds (11 and $\mathbf{1 2} \mathbf{a}-\mathbf{c})$

the alkylation procedure. Subsequently, the condensation of the corresponding $\mathbf{3 a}-\mathbf{m}, \mathbf{4 a}-\mathbf{v}, \mathbf{9}, \mathbf{1 0 a}-\mathbf{c}$ with thiosemicarbazide was carried out in anhydrous alcohol using acetic acid as catalyst to provide the desired target compounds $\mathbf{5 a}-\mathbf{m}, \mathbf{6 a}-\mathbf{v}$, 11 and $\mathbf{1 2 a}-\mathbf{c}$ in good to excellent yields, and their structures were characterized by MS, ${ }^{1} \mathrm{H}-\mathrm{NMR},{ }^{13} \mathrm{C}-\mathrm{NMR}$ spectra and element analysis.

\section{Biological Activity}

Inhibitory Effects of $\mathbf{5 a}-\mathbf{m}, \mathbf{6 a}-\mathbf{v}, \mathbf{1 1}$ and $\mathbf{1 2} \mathbf{a}-\mathbf{c}$ on Mushroom Tyrosinase

1-(1-Phenylethylidene)thiosemicarbazide had a potent inhibitory activity on mushroom tyrosinase with $\mathrm{IC}_{50}$ value of $0.34 \mu \mathrm{M}^{45)}$ Inspired by this and with the established threedimensional structure ${ }^{57-59)}$ of tyrosinase in mind, the inhibitory effects of our synthetic thiosemicarbazide derivatives, $\mathbf{5 a}-\mathbf{m}, \mathbf{6} \mathbf{a}-\mathbf{v}, \mathbf{1 1}$ and $\mathbf{1 2} \mathbf{a}-\mathbf{c}$, on mushroom tyrosinase were investigated, in which the well-known tyrosinase inhibitor, kojic acid, and its parental compounds acetophenone and thiosemicarbazide were employed as the standard references. The corresponding results were listed in Table 1. As predicted, all the structured-based condensation products displayed effective tyrosinase inhibitory activities, which was in good agreement with our speculation.

From Table 1, the following SARs results could be derived:

a) $\mathbf{5 a}-\mathbf{m}, \mathbf{6 a}-\mathbf{v}, 11$ and $12 \mathbf{a}-\mathbf{c}$, a total of thirty-nine compounds were synthesized, and thirty-one of them showed more potent tyrosinase inhibitory activities than the well-known tyrosinase inhibitor kojic acid with $\mathrm{IC}_{50}$ values below $1 \mu \mathrm{M}$.

b) From Fig. 2 we find that for 1-phenylethylidenethiosemicarbazide compounds, the introduction of hydroxy or amino group could not promote their inhibitory activity comparing with unsubstituted 1-(1-phenylethylidene)thiosemicarbazide $\left(\mathrm{IC}_{50}\right.$ value, $\left.\left.0.34 \mu \mathrm{M}\right),{ }^{45}\right)$ indicating that hydrophilic group is not favorable substituent, even is disadvantageous one, such as in 1-(2,4,6-tyihydroxyphenyl)ethylidenethiosemi-carbazide $\left(\mathrm{IC}_{50}\right.$ value, $\left.22.0 \mu \mathrm{M}\right){ }^{45)}$

c) Compared to unsubstituted 1-(1-phenylethylidene)thiosemicarbazide, compounds 5l, 5m, 6b, 6f, 6r, 6s, 6t, 6u 
Table 1. Structures and $\mathrm{IC}_{50}$ Values of 1-(3-Alkoxyphenyl)ethylidenethiosemicarbazide Compounds (5a-m), 1-(4-Alkoxyphenyl)ethylidenethiosemicarbazide Compounds (6a-v), 2-(4-(3-Hydroxypropoxy)benzylidene)hydrazine-1-carbothioamide (11) and 2-(3-Alkoxy-benzylidene)hydrazine-1-carbothioamide Compounds (12a-c)

\begin{tabular}{|c|c|c|c|c|c|}
\hline Entry & Alkoxy group structure & $\mathrm{IC}_{50}(\mu \mathrm{M})$ & Entry & Alkoxy group structure & $\mathrm{IC}_{50}(\mu \mathrm{M})$ \\
\hline $5 \mathbf{a}$ & $\mathrm{C}_{2} \mathrm{H}_{5}$ & 0.848 & $6 f$ & $\left(\mathrm{CH}_{2}\right)_{3} \mathrm{OH}$ & 0.334 \\
\hline $5 \mathbf{b}$ & $n-\mathrm{C}_{3} \mathrm{H}_{7}$ & 0.748 & $6 \mathrm{~g}$ & $n-\mathrm{C}_{4} \mathrm{H}_{9}$ & 0.408 \\
\hline $5 c$ & $n-\mathrm{C}_{4} \mathrm{H}_{9}$ & 0.620 & $6 \mathrm{~h}$ & iso- $\mathrm{C}_{4} \mathrm{H}_{9}$ & 0.353 \\
\hline 5d & $\left(\mathrm{CH}_{2}\right)_{4} \mathrm{Cl}$ & 0.525 & $6 \mathbf{i}$ & $\left(\mathrm{CH}_{2}\right)_{4} \mathrm{Cl}$ & 0.432 \\
\hline $5 e$ & $n-\mathrm{C}_{5} \mathrm{H}_{11}$ & 0.768 & $6 \mathbf{j}$ & $n-\mathrm{C}_{5} \mathrm{H}_{11}$ & 0.269 \\
\hline $5 f$ & iso- $\mathrm{C}_{5} \mathrm{H}_{11}$ & 1.040 & $6 \mathbf{k}$ & $n-\mathrm{C}_{6} \mathrm{H}_{13}$ & 0.404 \\
\hline $5 \mathrm{~g}$ & $n-\mathrm{C}_{6} \mathrm{H}_{13}$ & 0.707 & 61 & Cyclohexyl & 0.251 \\
\hline $5 \mathrm{~h}$ & $n-\mathrm{C}_{8} \mathrm{H}_{17}$ & 1.061 & $6 \mathrm{~m}$ & $n-\mathrm{C}_{7} \mathrm{H}_{15}$ & 0.790 \\
\hline $5 i$ & $\mathrm{CH}_{2} \mathrm{Ph}$ & 0.690 & $6 n$ & $n-\mathrm{C}_{8} \mathrm{H}_{17}$ & 1.091 \\
\hline $5 \mathbf{j}$ & $\mathrm{CH}_{2} \mathrm{PhBr}-4$ & 0.353 & 60 & Phenyl & 0.237 \\
\hline $5 \mathrm{k}$ & $\left(\mathrm{CH}_{2}\right)_{3} \mathrm{Ph}$ & 1.152 & $6 p$ & $\mathrm{CH}_{2} \mathrm{PhBr}-4$ & 0.566 \\
\hline 51 & $\mathrm{CH}_{2} \mathrm{CO}_{2} \mathrm{C}_{2} \mathrm{H}_{5}$ & 0.590 & $6 q$ & $\left(\mathrm{CH}_{2}\right)_{3} \mathrm{Ph}$ & 0.699 \\
\hline $5 \mathrm{~m}$ & $\left(\mathrm{CH}_{2}\right)_{3} \mathrm{CO}_{2} \mathrm{C}_{2} \mathrm{H}_{5}$ & 0.828 & $6 r$ & $\mathrm{CH}_{2} \mathrm{CO}_{2} \mathrm{C}_{2} \mathrm{H}_{5}$ & 0.439 \\
\hline Ref. & Acetophenones & $>100$ & $6 \mathrm{~s}$ & $\mathrm{CH}_{2} \mathrm{CO}_{2} \mathrm{H}$ & 0.686 \\
\hline Ref. & Thiosemicarbazide & $>100$ & $6 t$ & $\left(\mathrm{CH}_{2}\right)_{3} \mathrm{CO}_{2} \mathrm{C}_{2} \mathrm{H}_{5}$ & 0.182 \\
\hline Ref. & Kojic acid & 28.5 & $6 u$ & $\left(\mathrm{CH}_{2}\right)_{3} \mathrm{CO}_{2} \mathrm{H}$ & 0.323 \\
\hline $6 a$ & $\mathrm{C}_{2} \mathrm{H}_{5}$ & 0.461 & $6 v$ & $\mathrm{CH}_{2} \mathrm{CH}\left(\mathrm{OC}_{2} \mathrm{H}_{5}\right)_{2}$ & 0.747 \\
\hline $6 b$ & $\mathrm{C}_{2} \mathrm{H}_{4} \mathrm{OH}$ & 0.260 & 11 & $\left(\mathrm{CH}_{2}\right)_{3} \mathrm{OH}$ & 1.017 \\
\hline $6 c$ & $n-\mathrm{C}_{3} \mathrm{H}_{7}$ & 0.365 & $12 \mathrm{a}$ & $\mathrm{C}_{2} \mathrm{H}_{5}$ & 2.250 \\
\hline 6d & $\mathrm{CH}_{2} \mathrm{CH}=\mathrm{CH}_{2}$ & 0.424 & $12 b$ & $n-\mathrm{C}_{3} \mathrm{H}_{7}$ & 1.361 \\
\hline $6 e$ & $\mathrm{CH}_{2} \mathrm{C} \equiv \mathrm{CH}$ & 0.564 & $12 \mathrm{c}$ & $n-\mathrm{C}_{4} \mathrm{H}_{9}$ & 1.150 \\
\hline
\end{tabular}

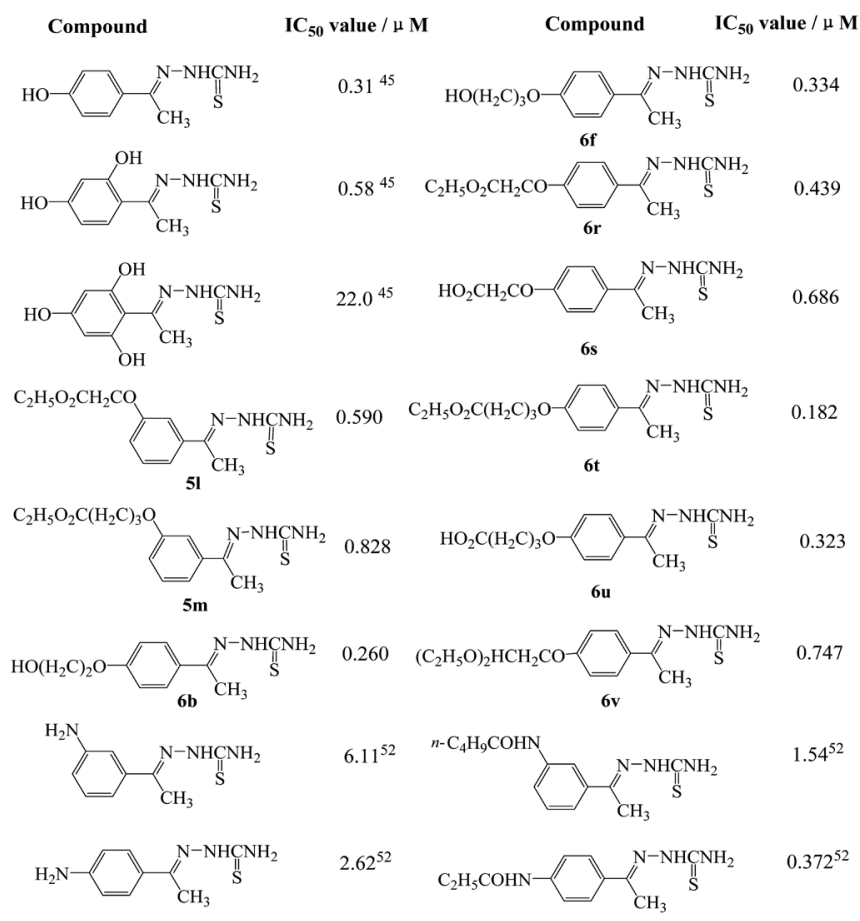

Fig. 2. Comparison of the Effect of Introducing Hydrophilic Groups on the Inhibitory Activity of Target Products

and $\mathbf{6 v}$, bearing a side chain with hydrophilic group at the top, all showed efficient inhibitory activities and their $\mathrm{IC}_{50}$ values were of the same order of magnitude $\left(\mathrm{IC}_{50}\right.$ values from 0.182 to $0.828 \mu \mathrm{M}$ ), showing that the type of hydrophilic group at the top of the chain has no obvious influence on inhibitory activity in the present investigation. Subsequently, comparing the $\mathrm{IC}_{50}$ values of compounds $5 \mathbf{l}, \mathbf{5 m}, \mathbf{6 b}, \mathbf{6 f}, \mathbf{6 r}, \mathbf{6 s}, \mathbf{6 t}, \mathbf{6} \mathbf{u}$ and $\mathbf{6 v}$ with that of compounds $5 \mathbf{a}-\mathbf{e}, \mathbf{6} \mathbf{a}, \mathbf{6} \mathbf{c}-\mathbf{e}$ and $\mathbf{6 g}-\mathbf{m}$, it could
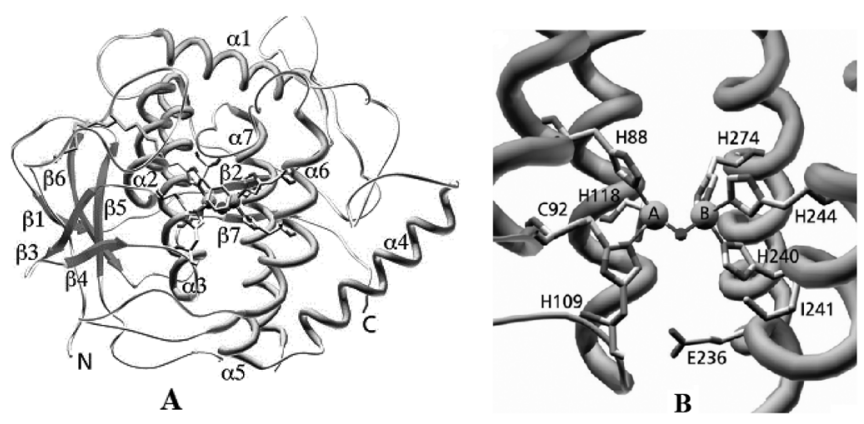

Fig. 3. Active Site Structure of Tyrosinase ${ }^{57-59)}$

be concluded that the type of the substituent chain (with or without hydrophilic group at the top) has no obvious influence on inhibitory activity.

d) We find from Fig. 2 that the introduction of the lipophilic group, hydroxyl or amino, to phenyl ring could enhance the inhibitory activity of thiosemicarbazone compounds, the reason for this phenomenon can be suggested as follows.

The active site structure of tyrosinase was shown in Fig. 3. ${ }^{57-59)}$ There is a lipophilic "narrow gorge" in the middle of the center of the enzyme and two copper ions are in middle of the "narrow gorge." It was found that there is a cap covering "narrow gorge" and the cap is consisted of 378 nucleotides $^{60,61)}$ which are flexible and prevent inhibitor binding to the active site of tyrosinase. ${ }^{57,62)}$

Thiosemicarbazone molecule needs to enter and pass through the "narrow gorge" before combining with two copper ions. As thiosemicarbazo group is hydrophilic and easy to bind to nucleotides through van der Waals' force. When the thiosemicarbazone molecule approaches the "nucleotide" cap, thiosemicarbazo group might induce the "nucleotide" cap to change its conformation, which could provide convenience for 


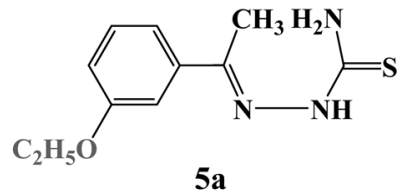

$5 a$

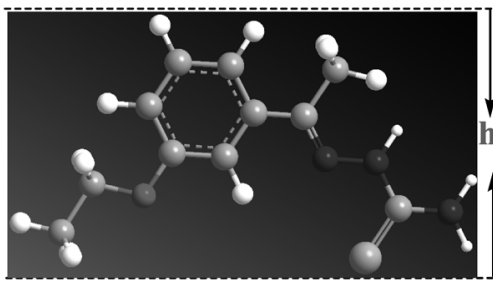

$5 \mathbf{a}$

Fig. 4. Structures of $\mathbf{5 a}, \mathbf{6 a}$ and Their Three-Dimension Structures ${ }^{75)}$

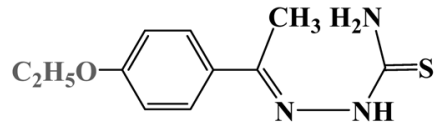

$6 a$

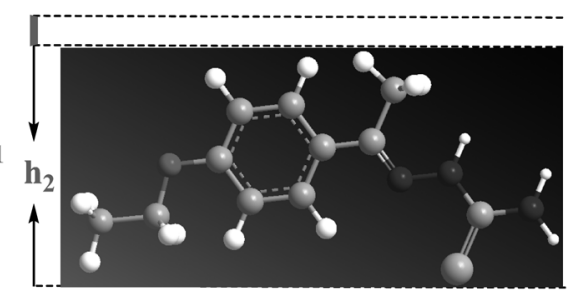

$6 \mathbf{a}$

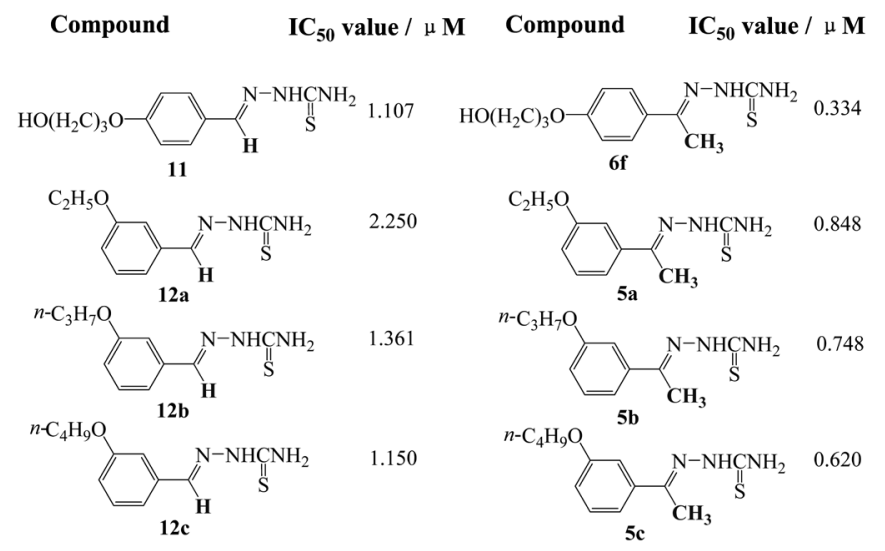

Fig. 5. Comparison of Structures and Inhibitory Activities of 1-Alkoxyphenylethylidene-thiosemicarbazide Compounds and 2-Alkoxybenzylidenehydrazine-1-carbothioamide Compounds

thiosemicarbazone molecule to enter the gorge. Subsequently, after the gate of the "narrow gorge" opens, the lipophilic characteristic of the other end of thiosemicarbazone molecule would promote thiosemicarbazone molecule to get into the "narrow gorge" and further, to push thiosemicarbazone molecule forward to the activity center of tyrosinase to combine with these two copper ions.

Therefore, the introduction of lipophilic group to the other end of the thiosemicarbazo group is benefit to enhance the inhibitory activity, but the lipophilicity and hydrophilicity of the two ends of thiosemicarbazone molecule should be properly adjusted, if the lipophilicity or hydrophilicity is too large the inhibitory activity of the molecule could be reduced.

e) In general, the compounds bearing the same alkoxy group at position-4 of the phenyl ring displayed more profound tyrosinase inhibitory activities than the ones bearing it at position-3 of the phenyl ring. For example, the $\mathrm{IC}_{50}$ value of 5a was $0.848 \mu \mathrm{M}$, but the $\mathrm{IC}_{50}$ value of $\mathbf{6 a}$ was $0.461 \mu \mathrm{M}$ (Table 1). The $\mathrm{IC}_{50}$ value of $\mathbf{5 m}$ was $0.828 \mu \mathrm{M}$ and the $\mathrm{IC}_{50}$ value of 6t was $0.182 \mu \mathrm{M}$. The results implied that the position of the alkoxy substituent influenced the tyrosinase inhibitory activity, and in the investigation, the alkoxy group attached at position- 4 of the phenyl ring was more efficacious for the inhibitory potency. It was consistent with previous reports by Kubo, ${ }^{63)}$ Jimenez $^{64)}$ and our recent report, ${ }^{52)}$ and this phenomenon is illustrated as follows through Fig. 4.

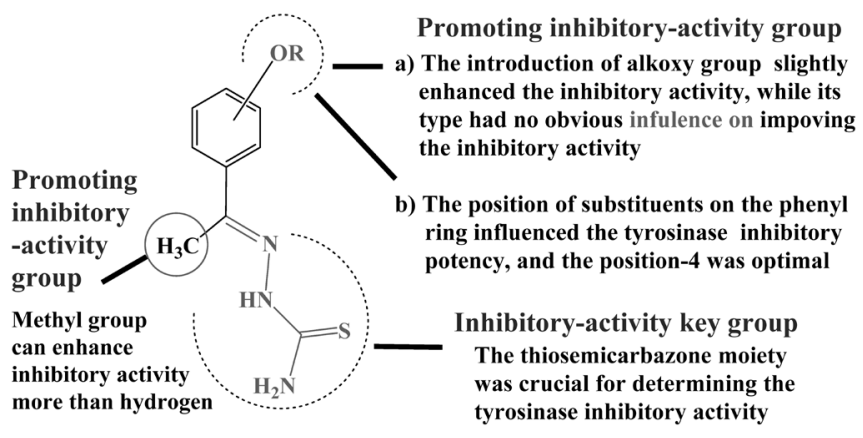

Fig. 6. SAR Analysis

From Fig. 4 it was found that the value of molecular section height of $5 \mathbf{a}$ is greater than that of $\mathbf{6 a}\left(\mathrm{h}_{1}>\mathrm{h}_{2}\right)$, which made 6a more favorable than 5a to enter and pass through the "narrow gorge" of tyrosinase, and then, to combine with these two copper ions in the center of tyrosinase. In addition, the difference of electronic effect of group at 3-positon or 4-positon of the phenyl ring on thiosemicarbazone group may also participate in and affect the inhibitory activity of these two compounds.

f) 1-Alkoxyphenylethylidenethiosemicarbazide compounds exhibited higher inhibitory activity than 2-alkoxybenzylidenehydrazine-1-carbothioamide compounds with about a two-fold of $\mathrm{IC}_{50}$ value, which indicated that on the benzylidene group of the molecule of thiosemicarbazide compounds methyl can enhance the activity more than hydrogen (Fig. 5). Therefore, methyl group on benzylidene unit is another important group to enhance inhibitory activity.

The above SAR results were summarized and illustrated in Fig. 6.

Inhibition Mechanism of Selected Compounds 5a and 6a on Tyrosinase The inhibition mechanism of compounds 5a and $\mathbf{6 a}$ against mushroom tyrosinase for the oxidation of $\mathrm{L}-$ DOPA was investigated and the relationship between enzyme activity and concentration of compounds $\mathbf{5} \mathbf{a}$ and $\mathbf{6 a}$ were respectively shown in Fig. 7. The results demonstrated that the plots gave a family of straight lines which all passed through the origin point. The increase of the inhibitor concentration resulted in the decrease of the line slope, indicating that the inhibitory action of compounds $\mathbf{5 a}$ and $\mathbf{6 a}$ on mushroom tyrosinase were reversible. ${ }^{45,65-69)}$ 

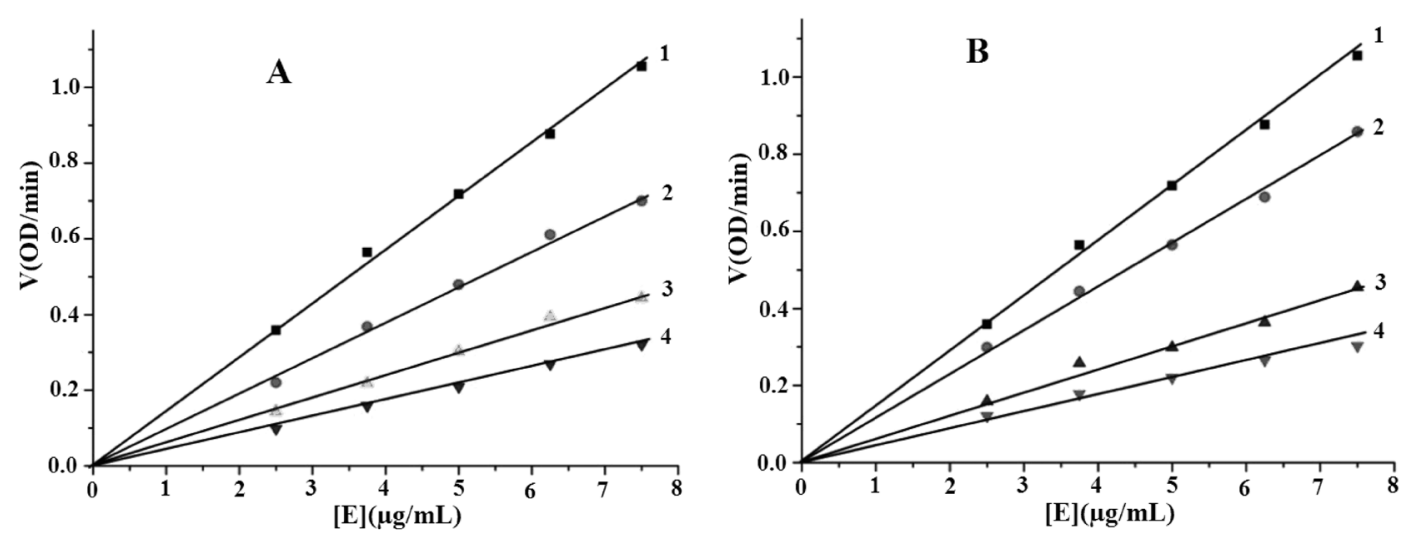

Fig. 7. Determination of the Inhibitory Effects of 5a (A) and 6a (B) on Mushroom Tyrosinase for the Oxidation of L-DOPA

The concentrations of compound $5 \mathbf{a}$ for curves $1-4$ were $0.0,0.5,1.0$ and $2.0 \mu \mathrm{M}$, respectively. The concentrations of compound $\mathbf{6 a}$ for curves $1-4$ were $0.0,0.1,0.5$ and $1.0 \mu \mathrm{M}$, respectively.
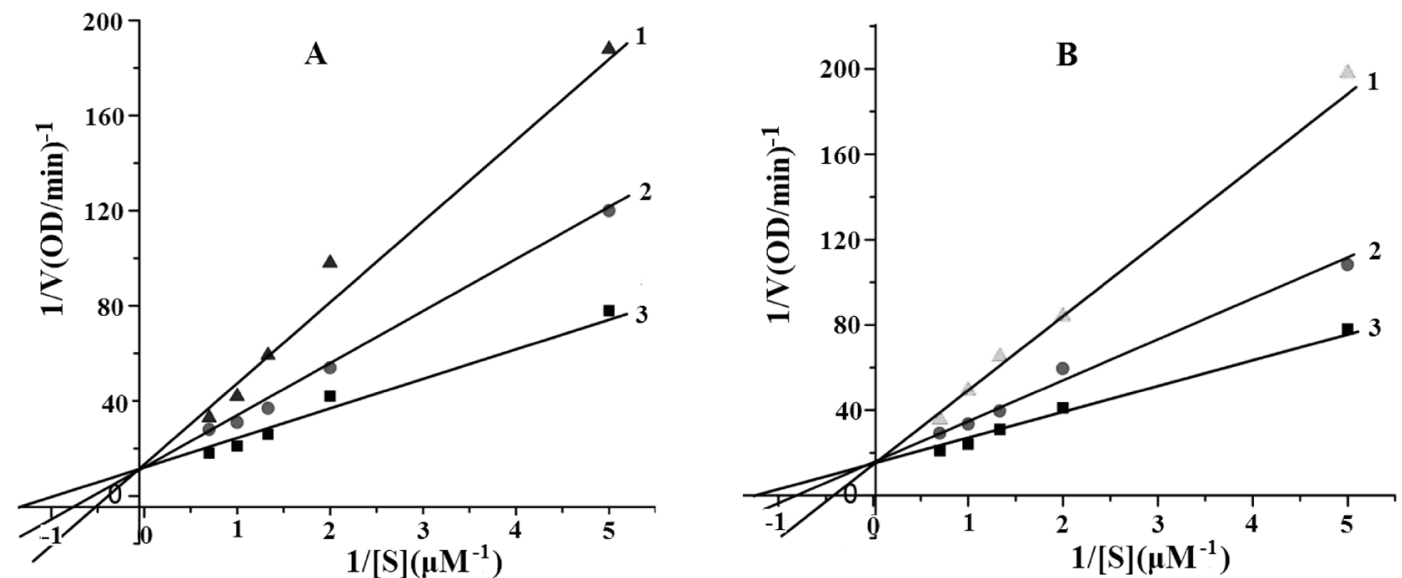

Fig. 8. Determination of the Inhibitory Types of Selected Compounds 5a (A) and $\mathbf{6 a}(\mathrm{B})$ on Tyrosinase for the Oxidation of L-DOPA

The concentrations of $\mathbf{5} \mathbf{a}$ for curves $1-3$ were $2.0,1.0$ and $0.5 \mu \mathrm{M}$, respectively. The concentrations of $\mathbf{6 a}$ for curves $1-3$ were $1.0,0.5$ and $0.1 \mu \mathrm{M}$, respectively.

Inhibitory Types of Selected Compounds 5a and 6a on Tyrosinase To further insight into the inhibitory mechanism, the inhibitory types of selected compounds $\mathbf{5 a}$ and $\mathbf{6 a}$ against mushroom tyrosinase for the oxidation of L-DOPA was determined by the Lineweaver-Burk double reciprocal plots with three different concentrations of inhibitors $\mathbf{5} \mathbf{a}$ and $\mathbf{6} \mathbf{a}$, respectively (Fig. 8 ). The results indicated that the plots of $1 / V$ versus $1 /[S]$ gave three straight lines with different slopes, and they intersected one another at the ordinate. The values of $V_{\max }$ remained the same and the values of $K_{\mathrm{m}}$ increased with the increase of inhibitor concentrations. The results demonstrated that compounds $\mathbf{5 a}$ and 6a were the competitive tyrosinase inhibitors and also suggested that they could only bind with the free enzyme., $3,47,52,64,70)$

Toxicity of Compounds 5a, 6e, 6g and 6t to 293T Cell Line The 293T cell line rarely express endogenous receptors required for extracellular ligands, and is easy to transfect, which is a very common cell line to express endogenous genes. In order to verify the safeties of these thiosemicarbazone compounds, four compounds $5 \mathbf{a}, \mathbf{6 e}, \mathbf{6 g}$ and $\mathbf{6 t}$, considering the diversity of structure and inhibition activity, were selected to test the cytotoxicity to the $293 \mathrm{~T}$ cell line. ${ }^{71-74)}$ As demonstrated in Fig. 9, the results showed that these compounds had no obvious growth inhibitory effect on the 293T cells at the concentrations of $0,31.25,62.5,125,250,500$, $1000 \mu \mathrm{mol} / \mathrm{L}$.
Since all of the selected compounds didn't show any obvious growth inhibition effect and toxicity to the 293T cell line even at a high concentration $(1000 \mu \mathrm{mol} / \mathrm{L})$, we concluded that the compounds designed and selected in this study have low cytotoxicity. In consideration of the cytotoxicity and promising inhibitory effects against tyrosinase, these compounds should have a broad application potential in food industry, agriculture and cosmetics for the treatment of tyrosinase-related disorders.

\section{Conclusion}

In summary, we developed for the first time thirty-nine 3-/4-alkoxy substituted phenylethylidenethiosemicarbazides as new, potent and safe tyrosinase inhibitors. The results showed that thirty-one structure-based compounds had remarkable inhibitory activities with $\mathrm{IC}_{50}$ value of lower than $1 \mu \mathrm{M}$, and among them compound $6 \mathbf{t}$ exhibited the highest inhibitory activity with an $\mathrm{IC}_{50}$ value of $0.182 \mu \mathrm{M}$. The SAR analysis indicated that: i) the type of alkoxy group has no obvious influence on the activity; ii) methyl group on benzylidene group can enhance inhibitory activities; iii) the position of the alkoxy group obviously influenced the activity, and in the investigation, the alkoxy group attached at position-4 was optimal. Moreover, the inhibition mechanism and the inhibitory kinetics of compounds 5a and 6a revealed that these com- 

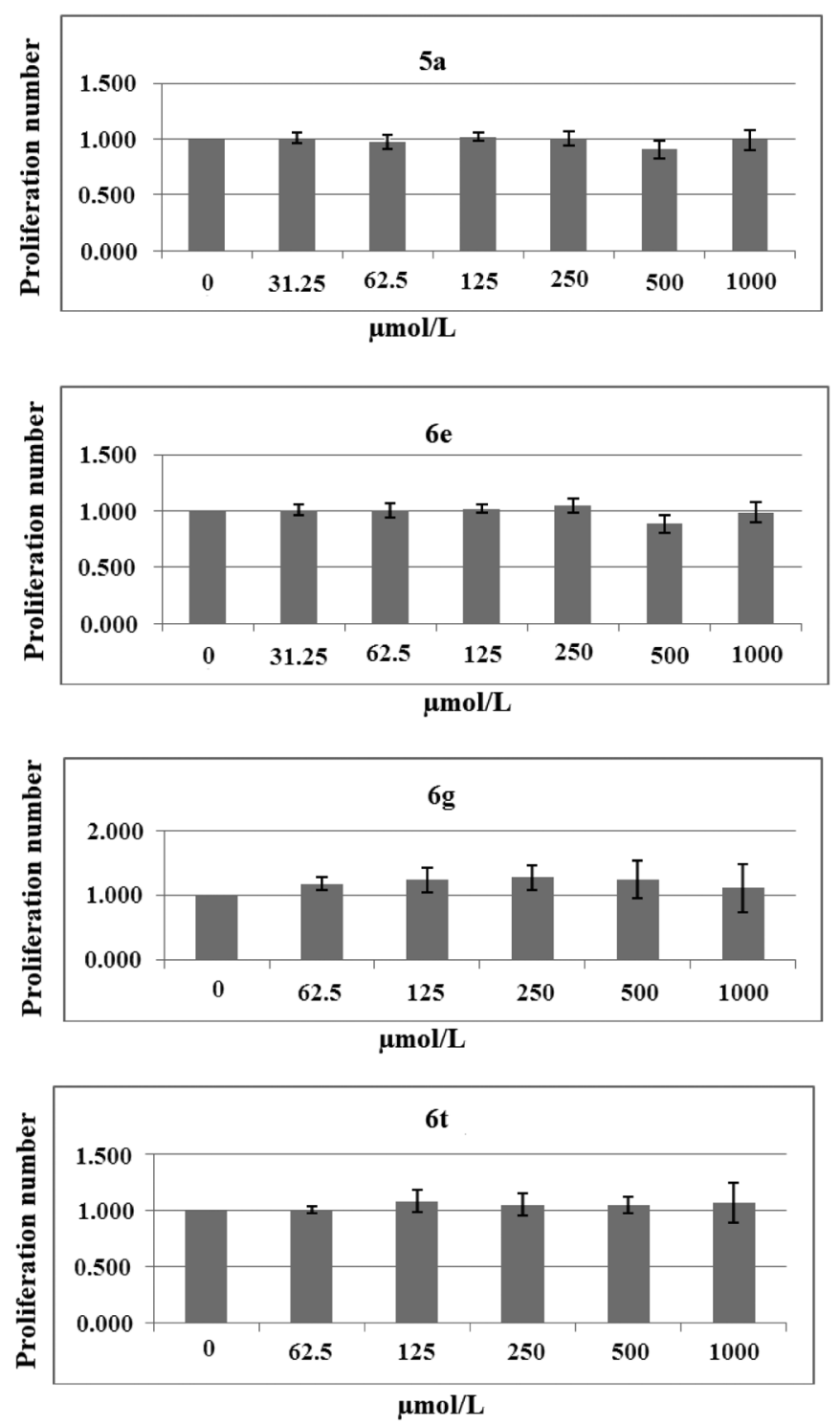

Fig. 9. Results of Cytotoxicity 5a, 6e, 69 and $\mathbf{6 t}$ to $293 \mathrm{~T}$ Cell Line

pounds exhibited such tyrosinase inhibitory effects by acting as a reversible and competitive inhibitor, and the process of the interaction was considered deeply between inhibitors and the active center of tyrosinase, based on the polarity characteristics of the two ends of inhibitors and structural characteristics of the active site of tyrosinase. Besides, the selected compounds $5 \mathbf{a}, \mathbf{6 e}, \mathbf{6 g}$ and $\mathbf{6 t}$ did not display any toxicity to the $293 \mathrm{~T}$ cell line even at the concentration of $1000 \mu \mathrm{mol} / \mathrm{L}$. Taken together, these results suggested that these compounds could serve as the promising candidates for the treatment of tyrosinase-related disorders. Further investigation of these compounds using human tyrosinase and a human melanoma cell line is being conduct, and the results will be reported in due course.

\section{Experimental}

General Melting points were determined on a WRS-1B digital instrument without correction. NMR spectra were recorded on a Varian Mercury-Plus 300 spectrometer in dimethyl sulfoxide (DMSO)- $d_{6}$. All chemical shifts $(\delta)$ were quoted in parts per million and coupling constants $(J)$ were given in Hertz. Mass spectra were obtained from VG ZAB-HS, LCMS-2010A or LCQ DECA XP spectrometer. Elemental analyses were performed on a Vario EL instrument and were within $\pm 0.4 \%$ of the theoretical values. All commercially available reagents and solvents were used without further purification. Mushroom tyrosinase (specific activity of the enzyme is $6680 \mathrm{U} / \mathrm{mg}$ ) and L-DOPA (L-3,4-dhydroxyphenylalanine) were purchased from Sigma Chemical Co.

Procedure for the Synthesis of Targeted Compounds 5a-m, 6a-v, 11 and 12a-c (Chart 1) Into $50 \mathrm{~mL}$ of anhydrous acetone were added $10.0 \mathrm{mmol}$ of compound $\mathbf{1}$ or $\mathbf{2}$, $13.0 \mathrm{mmol}$ of the corresponding alkoxy bromide or alkyl iodide and $20.0 \mathrm{mmol}$ of $\mathrm{K}_{2} \mathrm{CO}_{3}$, the above mixture was stirred at room temperature for $4-8 \mathrm{~h}$. After completion of the reaction as indicated by TLC, the reaction mixture was filtered and the solvent was removed by evaporation at vacuum to get crude products, followed by chromatography to provide the pure intermediates $\mathbf{3 a}-\mathbf{m}, \mathbf{4 a}-\mathbf{n}, \mathbf{4} \mathbf{p}-\mathbf{v}$. Compounds $\mathbf{9}$ and $10 a-c$ were prepared as the same method. Then, they respectively reacted with thiosemicarbazide in the presence of acetic acid $(0.5 \mathrm{~mL})$ at $50-80^{\circ} \mathrm{C}$ for $3 \mathrm{~h}$ to deliver the desired prod- 
ucts $5 \mathbf{a}-\mathbf{m}, \mathbf{6 a}-\mathbf{v}, 11$ and $12 \mathbf{a}-\mathbf{c}$.

2 - (1 - (3 - Ethoxy phenyl)ethylidene)hydrazine-1carbothioamide (5a)

Solid product, yield $81 \%, \mathrm{mp} \quad 152-153^{\circ} \mathrm{C} .{ }^{1} \mathrm{H}-\mathrm{NMR}$ $\left(300 \mathrm{MHz}, \mathrm{DMSO}-d_{6}\right) \delta: 10.15(\mathrm{~s}, 1 \mathrm{H}), 8.25(\mathrm{~s}, 1 \mathrm{H}), 7.91(\mathrm{~s}$, $1 \mathrm{H}), 7.46-7.37$ (m, 2H), 7.26 (t, $J=7.9 \mathrm{~Hz}, 1 \mathrm{H}), 6.95-6.89$ (m, $1 \mathrm{H}), 4.06(\mathrm{q}, J=6.9 \mathrm{~Hz}, 2 \mathrm{H}), 2.27(\mathrm{~s}, 3 \mathrm{H}), 1.32(\mathrm{t}, J=6.9 \mathrm{~Hz}$, $3 \mathrm{H}) .{ }^{13} \mathrm{C}-\mathrm{NMR}\left(75 \mathrm{MHz}, \mathrm{DMSO}-d_{6}\right) \delta: 178.8,158.5,147.8$, 139.1, 129.2, 119.0, 115.3, 112.4, 63.0, 14.6, 14.2. Electrospray ionization (ESI)-MS, $m / z=238.2[\mathrm{M}+\mathrm{H}]^{+}$. Anal. Calcd for $\mathrm{C}_{11} \mathrm{H}_{15} \mathrm{~N}_{3} \mathrm{OS}: \mathrm{C}, 55.67 ; \mathrm{H}, 6.37 ; \mathrm{N}, 17.71$. Found $\mathrm{C}, 55.99 ; \mathrm{H}$, 6.39; N, 17.79 .

2 - (1 - (3 - Propoxy phenyl)ethylidene)hydrazine-1carbothioamide $\mathbf{( 5 b )}$

Solid product, yield $82 \%, \quad \mathrm{mp} \quad 114-115^{\circ} \mathrm{C} .{ }^{1} \mathrm{H}-\mathrm{NMR}$ $\left(300 \mathrm{MHz}, \mathrm{DMSO}-d_{6}\right) \delta: 10.23(\mathrm{~s}, 1 \mathrm{H}), 8.33$ (s, 1H), 7.98 (s, $1 \mathrm{H}), 7.46(\mathrm{dd}, J=7.4,1.1 \mathrm{~Hz}, 2 \mathrm{H}), 7.29(\mathrm{t}, J=8.1 \mathrm{~Hz}, 1 \mathrm{H})$, 6.98-6.92 (m, 1H), $3.97(\mathrm{t}, J=6.5 \mathrm{~Hz}, 2 \mathrm{H}), 2.31(\mathrm{~s}, 3 \mathrm{H})$, $1.82-1.66(\mathrm{~m}, 2 \mathrm{H}), 1.00(\mathrm{t}, J=7.4 \mathrm{~Hz}, 3 \mathrm{H}) .{ }^{13} \mathrm{C}-\mathrm{NMR}(75 \mathrm{MHz}$, DMSO- $\left.d_{6}\right) \delta: 178.9,158.7,147.9,139.1,129.2,119.0,115.2$, $112.4,68.9,22.1,14.2,10.4$. ESI-MS $m / z=252.2[\mathrm{M}+\mathrm{H}]^{+}$. Anal. Calcd for $\mathrm{C}_{12} \mathrm{H}_{17} \mathrm{~N}_{3} \mathrm{OS}$ : C, 57.34; H, 6.82; N, 16.72 . Found C, 57.45; H, 6.78; N, 16.66.

2 - ( 1 - (3 - Butoxy phenyl)ethylidene)hydrazine-1carbothioamide (5c)

Solid product, yield 78\%, mp $105-106^{\circ} \mathrm{C} .{ }^{1} \mathrm{H}-\mathrm{NMR}$ $\left(300 \mathrm{MHz}, \mathrm{DMSO}-d_{6}\right) \delta: 10.14(\mathrm{~s}, 1 \mathrm{H}), 8.24(\mathrm{~s}, 1 \mathrm{H}), 7.91(\mathrm{~s}$, $1 \mathrm{H}), 7.46-7.36(\mathrm{~m}, 2 \mathrm{H}), 7.25(\mathrm{t}, J=7.9 \mathrm{~Hz}, 1 \mathrm{H}), 6.97-6.89(\mathrm{~m}$, $1 \mathrm{H}), 4.00(\mathrm{t}, J=6.4 \mathrm{~Hz}, 1 \mathrm{H}), 1.76-1.61(\mathrm{~m}, 1 \mathrm{H}), 1.50-1.37(\mathrm{~m}$, $1 \mathrm{H}), 0.92(\mathrm{t}, J=7.3 \mathrm{~Hz}, 1 \mathrm{H}) .{ }^{13} \mathrm{C}-\mathrm{NMR}\left(75 \mathrm{MHz}, \mathrm{DMSO}-d_{6}\right) \delta$ : $178.8,158.7,148.0,139.1,129.2,119.0,115.3,112.40,7.1,30.8$, 18.7, 14.2, 13.7. ESI-MS $m / z=266.2[\mathrm{M}+\mathrm{H}]^{+}$. Anal. Calcd for $\mathrm{C}_{13} \mathrm{H}_{19} \mathrm{~N}_{3} \mathrm{OS}$ : C, 58.84; H, 7.22; N, 15.83. Found C, 59.06; H, $7.18 ; \mathrm{N}, 15.86$.

2-(1-(3-(4-Chlorobutoxy)phenyl)ethylidene)hydrazine-1carbothioamide (5d)

Solid product, yield $74 \%$, mp $114-115^{\circ} \mathrm{C} . \quad{ }^{1} \mathrm{H}-\mathrm{NMR}$ $\left(300 \mathrm{MHz}, \mathrm{DMSO}-d_{6}\right) \delta: 10.15(\mathrm{~s}, 1 \mathrm{H}), 8.26(\mathrm{~s}, 1 \mathrm{H}), 7.91(\mathrm{~s}$, $1 \mathrm{H}), 7.43$ (d, $J=8.9 \mathrm{~Hz}, 2 \mathrm{H}), 7.26(\mathrm{t}, J=7.9 \mathrm{~Hz}, 1 \mathrm{H}), 6.93$ (d, $J=8.1 \mathrm{~Hz}, 1 \mathrm{H}), 4.04(\mathrm{t}, J=5.3 \mathrm{~Hz}, 2 \mathrm{H}), 3.70(\mathrm{t}, J=5.7 \mathrm{~Hz}$, $2 \mathrm{H}), 2.27(\mathrm{~s}, 3 \mathrm{H}), 1.99-1.75(\mathrm{~m}, 4 \mathrm{H}) .{ }^{13} \mathrm{C}-\mathrm{NMR}(75 \mathrm{MHz}$, DMSO- $\left.d_{6}\right) \delta: 178.8,158.5,147.9,139.1,129.2,119.1,115.4$, 112.4, 66.7, 5.2, 28.9, 26.13, 14.2. ESI-MS $m / z=300.3$ $[\mathrm{M}+\mathrm{H}]^{+}$. Anal. Calcd for $\mathrm{C}_{13} \mathrm{H}_{18} \mathrm{ClN}_{3} \mathrm{OS}: \mathrm{C}, 52.08 ; \mathrm{H}, 6.05 ; \mathrm{N}$, 14.02. Found C, 52.31; H, 6.08; N, 13.91.

2 - (1 - (3 - Pentoxy phenyl)ethylidene)hydrazine-1carbothioamide (5e)

Solid product, yield $78 \%$, mp $103-104^{\circ} \mathrm{C} .{ }^{1} \mathrm{H}-\mathrm{NMR}$ $\left(300 \mathrm{MHz}, \mathrm{DMSO}-d_{6}\right) \delta: 10.23(\mathrm{~s}, 1 \mathrm{H}), 8.33$ (s, 1H), 7.97 (s, $1 \mathrm{H}), 7.46$ (d, $J=7.6 \mathrm{~Hz}, 2 \mathrm{H}), 7.29$ (t, $J=7.9 \mathrm{~Hz}, 1 \mathrm{H}), 6.99-6.90$ $(\mathrm{m}, 1 \mathrm{H}), 4.00(\mathrm{t}, J=6.4 \mathrm{~Hz}, 2 \mathrm{H}), 2.31(\mathrm{~s}, 3 \mathrm{H}), 1.78-1.62(\mathrm{~m}$, $2 \mathrm{H}), 1.47-1.25(\mathrm{~m}, 4 \mathrm{H}), 0.90(\mathrm{t}, J=7.1 \mathrm{~Hz}, 3 \mathrm{H}) .{ }^{13} \mathrm{C}-\mathrm{NMR}$ $\left(75 \mathrm{MHz}, \mathrm{DMSO}-d_{6}\right) \delta$ : 177.20, 157.00, 146.17, 137.40, 127.52, $117.28,113.53,110.74,65.74,26.76,26.09,20.25,12.55,12.22$. ESI-MS $m / z=280.3[\mathrm{M}+\mathrm{H}]^{+}$. Anal. Calcd for $\mathrm{C}_{14} \mathrm{H}_{21} \mathrm{~N}_{3} \mathrm{OS}$ : C, 60.18; H, 7.58; N, 15.04. Found C, 60.33; H, 7.47; N, 15.02.

2-(1-(3-iso-Pentoxy phenyl)ethylidene)hydrazine-1carbothioamide (5f)

Solid product, yield 79\%, mp $120-121^{\circ} \mathrm{C} .{ }^{1} \mathrm{H}-\mathrm{NMR}$ $\left(300 \mathrm{MHz}, \mathrm{DMSO}-d_{6}\right) \delta: 10.19(\mathrm{~s}, 1 \mathrm{H}), 8.28(\mathrm{~s}, 1 \mathrm{H}), 7.94(\mathrm{~s}$, 1H), $7.49-7.38(\mathrm{~m}, 2 \mathrm{H}), 7.28$ (t, $J=7.9 \mathrm{~Hz}, 1 \mathrm{H}), 6.96$ (dd,
$J=8.1,1.9 \mathrm{~Hz}, 1 \mathrm{H}), 4.04(\mathrm{t}, J=6.6 \mathrm{~Hz}, 2 \mathrm{H}), 2.29(\mathrm{~s}, 3 \mathrm{H})$, $1.88-1.71(\mathrm{~m}, 1 \mathrm{H}), 1.65-1.57(\mathrm{~m}, 2 \mathrm{H}), 0.93(\mathrm{~d}, J=6.6 \mathrm{~Hz}, 6 \mathrm{H})$. ${ }^{13} \mathrm{C}-\mathrm{NMR}\left(75 \mathrm{MHz}, \mathrm{DMSO}-d_{6}\right) \delta$ : 178.8, 158.7, 147.9, 139.1, 129.2, 119.0, 115.3, 112.4, 65.8, 37.5, 24.5, 22.4, 14.2. ESI-MS $m / z=280.3[\mathrm{M}+\mathrm{H}]^{+}$. Anal. Calcd for $\mathrm{C}_{14} \mathrm{H}_{21} \mathrm{~N}_{3} \mathrm{OS}: \mathrm{C}, 60.18$; H, 7.58; N, 15.04. Found C, 60.48; H, 7.54; N, 15.10.

2 - (1 - (3 - Hexoxy phenyl)ethylidene)hydrazine-1carbothioamide $(\mathbf{5 g})$

Solid product, yield $82 \%$, mp $102-103^{\circ} \mathrm{C} .{ }^{1} \mathrm{H}-\mathrm{NMR}$ $\left(300 \mathrm{MHz}, \mathrm{DMSO}-d_{6}\right) \delta: 10.19(\mathrm{~s}, 1 \mathrm{H}), 8.29$ (s, 1H), 7.94 (s, $1 \mathrm{H}), 7.48-7.49(\mathrm{~m}, 2 \mathrm{H}), 7.28(\mathrm{t}, J=7.9 \mathrm{~Hz}, 1 \mathrm{H}), 6.95$ (dd, $J=8.1,1.9 \mathrm{~Hz}, 1 \mathrm{H}), 4.01(\mathrm{t}, J=6.4 \mathrm{~Hz}, 2 \mathrm{H}), 2.29(\mathrm{~s}, 3 \mathrm{H})$, $1.79-1.62(\mathrm{~m}, 2 \mathrm{H}), 1.51-1.20(\mathrm{~m}, 6 \mathrm{H}), 0.88(\mathrm{t}, J=6.9 \mathrm{~Hz}, 3 \mathrm{H})$. ${ }^{13} \mathrm{C}-\mathrm{NMR}\left(75 \mathrm{MHz}, \mathrm{DMSO}-d_{6}\right) \delta$ : 178.8, 158.7, 147.9, 139.1, 129.2, 119.0, 115.3, 112.4, 67.4, 31.0, 28.7, 25.2, 22.1, 14.2, 13.9. ESI-MS $m / z=294.3[\mathrm{M}+\mathrm{H}]^{+}$.

2 -(1 - (3 - Octyloxy phenyl)ethylidene)hydrazine-1carbothioamide $\mathbf{( 5 h})$

Solid product, yield $72 \%, \mathrm{mp} \quad 107-108^{\circ} \mathrm{C} .{ }^{1} \mathrm{H}-\mathrm{NMR}$ $\left(300 \mathrm{MHz}, \mathrm{DMSO}-d_{6}\right) \delta: 10.18(\mathrm{~s}, 1 \mathrm{H}), 8.28(\mathrm{~s}, 1 \mathrm{H}), 7.94(\mathrm{~s}$, $1 \mathrm{H}), 7.48-7.49(\mathrm{~m}, 2 \mathrm{H}), 7.28(\mathrm{t}, J=7.9 \mathrm{~Hz}, 1 \mathrm{H}), 6.95$ (dd, $J=8.1,2.0 \mathrm{~Hz}, 1 \mathrm{H}), 4.00(\mathrm{t}, J=6.4 \mathrm{~Hz}, 2 \mathrm{H}), 2.28(\mathrm{~s}, 3 \mathrm{H})$, $1.79-1.62(\mathrm{~m}, 2 \mathrm{H}), 1.51-1.17(\mathrm{~m}, 10 \mathrm{H}), 0.86(\mathrm{t}, J=6.9 \mathrm{~Hz}, 3 \mathrm{H})$. ${ }^{13} \mathrm{C}-\mathrm{NMR}\left(75 \mathrm{MHz}, \mathrm{DMSO}-d_{6}\right) \delta$ : 178.8, 158.7, 147.9, 139.1, $129.2,119.0,115.3,112.4,67.4,31.2,28.7,28.7,28.7,25.6$, 22.1, 14.2, 13.9. ESI-MS $m / z=322.4[\mathrm{M}+\mathrm{H}]^{+}$. Anal. Calcd for $\mathrm{C}_{17} \mathrm{H}_{27} \mathrm{~N}_{3} \mathrm{OS}$ : C, 63.51; H, 8.47; N, 13.07. Found C, 63.62; H, 8.40; N, 13.13 .

2-(1-(3-Benzyloxy phenyl)ethylidene)hydrazine-1carbothioamide $\mathbf{( 5 \mathbf { i } )}$

Solid product, yield $86 \%, \mathrm{mp} \quad 143-144^{\circ} \mathrm{C} .{ }^{1} \mathrm{H}-\mathrm{NMR}$ $\left(300 \mathrm{MHz}, \mathrm{DMSO}-d_{6}\right) \delta: 10.21(\mathrm{~s}, 1 \mathrm{H}), 8.32(\mathrm{~s}, 1 \mathrm{H}), 7.93$ (s, 1H), 7.57-7.54 (m, 1H), 7.50-7.29 (m, 7H), 7.04 (dd, $J=8.0,2.1 \mathrm{~Hz}, 1 \mathrm{H}), 5.17(\mathrm{~s}, 2 \mathrm{H}), 2.29$ (s, 3H). ${ }^{13} \mathrm{C}-\mathrm{NMR}$ $\left(75 \mathrm{MHz}, \mathrm{DMSO}-d_{6}\right) \delta: 178.9,158.3,147.7,139.1,137.1,129.3$, $128.4,127.8,127.7,119.4,115.8,112.6,69.3,14.2$. ESI-MS $m / z=300.3[\mathrm{M}+\mathrm{H}]^{+}$.

2-(1-(3-((4-Bromobenzyl)oxy)phenyl)ethylidene)hydrazine-1-carbothioamide $(\mathbf{5 j} \mathbf{j})$

Solid product, yield $83 \%$, mp $163-164^{\circ} \mathrm{C} .{ }^{1} \mathrm{H}-\mathrm{NMR}$ $\left(300 \mathrm{MHz}, \mathrm{DMSO}-d_{6}\right) \delta: 10.28(\mathrm{~s}, 1 \mathrm{H}), 8.40(\mathrm{~s}, 1 \mathrm{H}), 8.00(\mathrm{~s}$, $1 \mathrm{H}), 7.63-7.55(\mathrm{~m}, 3 \mathrm{H}), 7.51-7.41(\mathrm{~m}, 3 \mathrm{H}), 7.32(\mathrm{t}, J=8.0 \mathrm{~Hz}$, $1 \mathrm{H}), 7.04$ (dd, $J=8.1,2.0 \mathrm{~Hz}, 1 \mathrm{H}), 5.16(\mathrm{~s}, 2 \mathrm{H}), 2.32$ (s, 3H). ${ }^{13} \mathrm{C}-\mathrm{NMR}\left(75 \mathrm{MHz}, \mathrm{DMSO}-d_{6}\right) \delta$ : 176.4, 155.6, 145.2, 136.6, 134.0, 128.8, 127.3, 126.8, 118.5, 117.0, 113.3, 110.1, 66.0, 11.7. ESI-MS $m / z=378.2[\mathrm{M}+\mathrm{H}]^{+}$. Anal. Calcd for $\mathrm{C}_{16} \mathrm{H}_{16} \mathrm{BrN}_{3} \mathrm{OS}$ : C, 50.80; H, 4.26; N, 11.11. Found C, 51.08; H, 4.35; N, 10.90.

2-(1-(3-(3-Phenylpropoxy)phenyl)ethylidene)hydrazine-1carbothioamide (5k)

Solid product, yield $81 \%$, mp $143-144^{\circ} \mathrm{C} . \quad{ }^{1} \mathrm{H}-\mathrm{NMR}$ $\left(300 \mathrm{MHz}, \mathrm{DMSO}-d_{6}\right) \delta: 10.21(\mathrm{~s}, 1 \mathrm{H}), 8.31(\mathrm{~s}, 1 \mathrm{H}), 7.96$ (s, $1 \mathrm{H}), 7.49-7.43(\mathrm{~m}, 2 \mathrm{H}), 7.36-7.13(\mathrm{~m}, 6 \mathrm{H}), 7.02-6.91(\mathrm{~m}$, $1 \mathrm{H}), 4.02(\mathrm{t}, J=6.3 \mathrm{~Hz}, 2 \mathrm{H}), 2.83-2.69(\mathrm{~m}, 2 \mathrm{H}), 2.30(\mathrm{~s}, 3 \mathrm{H})$, 2.11-1.95 (m, 2H). ${ }^{13} \mathrm{C}-\mathrm{NMR}\left(75 \mathrm{MHz}, \mathrm{DMSO}-d_{6}\right) \delta: 178.9$, $158.6,147.9,141.4,139.1,129.3,128.3,125.8,119.1,115.3$, $112.5,66.7,31.5,30.4,14.2$. ESI-MS $m / z=328.3[\mathrm{M}+\mathrm{H}]^{+}$. Anal. Calcd for $\mathrm{C}_{18} \mathrm{H}_{21} \mathrm{~N}_{3} \mathrm{OS}: \mathrm{C}, 66.02 ; \mathrm{H}, 6.46 ; \mathrm{N}, 12.83$. Found C, 66.16; H, 6.47; N, 12.73 .

Ethyl 2-(3-(1-(2-Carbamothioylhydrazono)ethyl)phenoxy)acetate (5l)

Solid product, yield $84 \%$, mp $154-155^{\circ} \mathrm{C} . \quad{ }^{1} \mathrm{H}-\mathrm{NMR}$ 
$\left(300 \mathrm{MHz}, \mathrm{DMSO}-d_{6}\right) \delta: 10.21(\mathrm{~s}, 1 \mathrm{H}), 8.32(\mathrm{~s}, 1 \mathrm{H}), 7.97$ (s, $1 \mathrm{H}), 7.55-7.42(\mathrm{~m}, 2 \overline{\mathrm{H}}), 7.34-7.27(\mathrm{~m}, 1 \mathrm{H}), 7.02-6.91(\mathrm{~m}$, $1 \mathrm{H}), 4.86$ (s, 2H), 4.17 (q, $J=7.1 \mathrm{~Hz}, 2 \mathrm{H}), 2.29$ (s, 3H), 1.21 $(\mathrm{t}, J=7.1 \mathrm{~Hz}, 3 \mathrm{H}) .{ }^{13} \mathrm{C}-\mathrm{NMR}\left(75 \mathrm{MHz}, \mathrm{DMSO}-d_{6}\right) \delta: 178.9$, 168.7, 157.6, 147.5, 139.1, 129.3, 119.8, 115.7, 112.1, 64.7, 60.6, 14.1, 14.0. ESI-MS $m / z=296.2[\mathrm{M}+\mathrm{H}]^{+}$. Anal. Calcd for $\mathrm{C}_{13} \mathrm{H}_{17} \mathrm{~N}_{3} \mathrm{O}_{3} \mathrm{~S}$ : C, 52.86; H, 5.80; N, 14.23. Found C, 53.08; H, $5.80 ; \mathrm{N}, 14.25$.

2-(1-(3-(4-(Ethylperoxy)butoxy)phenyl)ethylidene)hydrazine-1-carbothioamide $(\mathbf{5 m})$

Solid product, yield $75 \%, \mathrm{mp} \quad 107-108^{\circ} \mathrm{C} .{ }^{1} \mathrm{H}-\mathrm{NMR}$ $\left(300 \mathrm{MHz}, \mathrm{DMSO}-d_{6}\right) \delta$ : $10.20(\mathrm{~s}, 1 \mathrm{H}), 8.30(\mathrm{~s}, 1 \mathrm{H}), 7.94(\mathrm{~s}$, $1 \mathrm{H}), 7.45$ (t, $J=5.8 \mathrm{~Hz}, 2 \mathrm{H}), 7.29$ (t, $J=7.9 \mathrm{~Hz}, 1 \mathrm{H}), 6.95$ (dd, $J=8.1,1.8 \mathrm{~Hz}, 1 \mathrm{H}), 4.15-3.98(\mathrm{~m}, 4 \mathrm{H}), 2.47(\mathrm{t}, J=7.3 \mathrm{~Hz}$, $2 \mathrm{H}), 2.29(\mathrm{~s}, 3 \mathrm{H}), 2.04-1.92(\mathrm{~m}, 2 \mathrm{H}), 1.18(\mathrm{t}, J=7.1 \mathrm{~Hz}$, $3 \mathrm{H}) .{ }^{13} \mathrm{C}-\mathrm{NMR}\left(75 \mathrm{MHz}, \mathrm{DMSO}-d_{6}\right) \delta: 178.8,172.6,158.4$, $147.8,139.1,129.3,119.2,115.3,112.4,66.5,59.9,30.1,24.2$ 14.2, 14.1. ESI-MS $m / z=324.3[\mathrm{M}+\mathrm{H}]^{+}$. Anal. Calcd for $\mathrm{C}_{15} \mathrm{H}_{21} \mathrm{~N}_{3} \mathrm{O}_{3} \mathrm{~S}$ : C, 55.71; H, 6.54; N, 12.99. Found C, 55.67; H, $6.51 ; \mathrm{N}, 13.02$.

2 - (1 - (4 -Ethoxyphenyl)ethylidene)hydrazine-1carbothioamide (6a)

Solid product, yield $85 \%, \mathrm{mp} \quad 153-154^{\circ} \mathrm{C} .{ }^{1} \mathrm{H}-\mathrm{NMR}$ $\left(300 \mathrm{MHz}, \mathrm{DMSO}-d_{6}\right) \delta$ : $10.15(\mathrm{~s}, 1 \mathrm{H}), 8.24(\mathrm{~s}, 1 \mathrm{H}), 7.88(\mathrm{~d}$, $J=8.9 \mathrm{~Hz}, 2 \mathrm{H}), 6.91(\mathrm{~d} J=8.9 \mathrm{~Hz}, 2 \mathrm{H}), 4.12-3.97(\mathrm{~m}, 2 \mathrm{H})$, $2.28(\mathrm{~s}, 3 \mathrm{H}), 1.34(\mathrm{t}, J=6.8 \mathrm{~Hz}, 3 \mathrm{H}) .{ }^{13} \mathrm{C}-\mathrm{NMR}(75 \mathrm{MHz}$, DMSO- $\left.d_{6}\right) \delta$ : 178.6, 159.5, 147.8, 129.8, 128.1, 113.9, 63.1, 14.6, 13.8. ESI-MS $m / z=238.2[\mathrm{M}+\mathrm{H}]^{+}$. Anal. Calcd for $\mathrm{C}_{11} \mathrm{H}_{15} \mathrm{~N}_{3} \mathrm{OS}$ : C, 55.67; H, 6.37; N, 17.71. Found C, 55.94; H, $6.39 ; \mathrm{N}, 17.79$.

2-(1-(4-(2-Hydroxyethoxy)phenyl)ethylidene)hydrazine-1carbothioamide $(\mathbf{6 b})$

Solid product, yield $83 \%, \quad \mathrm{mp} \quad 217-218^{\circ} \mathrm{C} . \quad{ }^{1} \mathrm{H}-\mathrm{NMR}$ $\left(300 \mathrm{MHz}, \mathrm{DMSO}-d_{6}\right) \delta: 10.09(\mathrm{~s}, 1 \mathrm{H}), 8.18(\mathrm{~s}, 1 \mathrm{H}), 7.86(\mathrm{~s}$, $1 \mathrm{H}), 7.84(\mathrm{~d}, J=8.6 \mathrm{~Hz}, 2 \mathrm{H}), 6.90(\mathrm{~d}, J=8.7 \mathrm{~Hz}, 2 \mathrm{H}), 4.86$ $(\mathrm{t}, J=5.4 \mathrm{~Hz}, 1 \mathrm{H}), 4.00(\mathrm{t}, J=4.7 \mathrm{~Hz}, 2 \mathrm{H}), 3.71(\mathrm{dd}, J=9.7$, $4.9 \mathrm{~Hz}, 2 \mathrm{H}), 2.25(\mathrm{~s}, 3 \mathrm{H}) .{ }^{13} \mathrm{C}-\mathrm{NMR}\left(75 \mathrm{MHz}, \mathrm{DMSO}-d_{6}\right) \delta$ $179.3,160.3,148.5,130.6,128.8,114.8,70.4,60.4,14.7$. ESIMS $m / z=254.3[\mathrm{M}+\mathrm{H}]^{+}$. Anal. Calcd for $\mathrm{C}_{11} \mathrm{H}_{15} \mathrm{~N}_{3} \mathrm{OS}: \mathrm{C}$, 52.15; H, 5.97; N, 16.59. Found C, 52.43; H, 5.88; N, 16.46 .

2 - (1 - ( 4 - Propoxy phenyl)ethylidene)hydrazine-1 carbothioamide (6c)

Solid product, yield $84 \%$, mp $185-186^{\circ} \mathrm{C} .{ }^{1} \mathrm{H}-\mathrm{NMR}$ $\left(300 \mathrm{MHz}, \mathrm{DMSO}-d_{6}\right) \delta$ : $10.17(\mathrm{~s}, 1 \mathrm{H}), 8.26(\mathrm{~s}, 1 \mathrm{H}), 7.96-7.83$ (m, 3H), 6.92 (d, $J=9.0 \mathrm{~Hz}, 2 \mathrm{H}), 3.94(\mathrm{t}, J=6.5 \mathrm{~Hz}, 2 \mathrm{H}), 2.28$ $(\mathrm{s}, 3 \mathrm{H}), 1.82-1.65(\mathrm{~m}, 2 \mathrm{H}), 0.98(\mathrm{t}, J=7.4 \mathrm{~Hz}, 3 \mathrm{H}) .{ }^{13} \mathrm{C}-\mathrm{NMR}$ $\left(75 \mathrm{MHz}, \mathrm{DMSO}-d_{6}\right) \delta: 178.6,159.6,147.8,129.8,128.1,114.0$, 68.9, 22.0, 13.8, 10.3. ESI-MS $m / z=252.2[\mathrm{M}+\mathrm{H}]^{+}$, Anal. Calcd for $\mathrm{C}_{12} \mathrm{H}_{17} \mathrm{~N}_{3} \mathrm{OS}$ : C, 57.34; H, 6.82; N, 16.72. Found $\mathrm{C}$, 57.46; H, 6.77; N, 16.64 .

2-(1-(4-(Allyloxy)phenyl)ethylidene)hydrazine-1carbothioamide (6d)

Solid product, yield $88 \%$, mp $157-158^{\circ} \mathrm{C} .{ }^{1} \mathrm{H}-\mathrm{NMR}$ $\left(300 \mathrm{MHz}, \mathrm{DMSO}-d_{6}\right) \delta: 10.16(\mathrm{~s}, 1 \mathrm{H}), 8.25(\mathrm{~s}, 1 \mathrm{H}), 7.89(\mathrm{~d}$, $J=8.9 \mathrm{~Hz}, 3 \mathrm{H}), 6.95(\mathrm{~d}, J=8.8 \mathrm{~Hz}, 2 \mathrm{H}), 6.11-6.00(\mathrm{~m}, 1 \mathrm{H})$, $5.41(\mathrm{~d}, J=15.9 \mathrm{~Hz}, 1 \mathrm{H}), 5.27(\mathrm{~d}, J=10.5 \mathrm{~Hz}, 1 \mathrm{H}), 4.60(\mathrm{~d}$, $J=5.1 \mathrm{~Hz}, 2 \mathrm{H}), 2.28(\mathrm{~s}, 3 \mathrm{H}) .{ }^{13} \mathrm{C}-\mathrm{NMR}\left(75 \mathrm{MHz}, \mathrm{DMSO}-d_{6}\right)$ $\delta: 178.6,159.1,147.8,133.5,130.1,128.1,117.5,114.2,68.2$, 13.8. ESI-MS $m / z=250.2[\mathrm{M}+\mathrm{H}]^{+}$.
2-(1-(4-(Prop-2-yn-1-yloxy)phenyl)ethylidene)hydrazine-1carbothioamide (6e)

Solid product, yield 78\%, mp $175-176^{\circ} \mathrm{C} .{ }^{1} \mathrm{H}-\mathrm{NMR}$ $\left(300 \mathrm{MHz}, \mathrm{DMSO}-d_{6}\right) \delta: 10.10(\mathrm{~s}, 1 \mathrm{H}), 8.19(\mathrm{~s}, 1 \mathrm{H}), 7.87(\mathrm{~d}$, $J=8.0 \mathrm{~Hz}, 3 \mathrm{H}), 6.95(\mathrm{~d}, J=8.5 \mathrm{~Hz}, 2 \mathrm{H}), 4.83(\mathrm{~s}, 2 \mathrm{H}), 3.56$ $(\mathrm{s}, 1 \mathrm{H}), 2.26(\mathrm{~s}, 3 \mathrm{H}) .{ }^{13} \mathrm{C}-\mathrm{NMR}\left(75 \mathrm{MHz}, \mathrm{DMSO}-d_{6}\right) \delta: 179.2$, 158.7, 148.3, 131.4, 128.7, 115.2, 79.8, 79.1, 56.3, 14.7. ESI-MS $m / z=248.2[\mathrm{M}+\mathrm{H}]^{+}$. Anal. Calcd for $\mathrm{C}_{12} \mathrm{H}_{13} \mathrm{~N}_{3} \mathrm{OS}$ : C, 58.28; H, 5.30; N, 16.99. Found C, 58.41; H, 5.35; N, 16.81 .

2-(1-(4-(3-Hydroxypropoxy)phenyl)ethylidene)hydrazine-1carbothioamide (6f)

Solid product, yield $78 \%, \mathrm{mp} \quad 176-177^{\circ} \mathrm{C} .{ }^{1} \mathrm{H}-\mathrm{NMR}$ $\left(300 \mathrm{MHz}, \mathrm{DMSO}-d_{6}\right) \delta: 10.07(\mathrm{~s}, 1 \mathrm{H}), 8.17(\mathrm{~s}, 1 \mathrm{H}), 7.84(\mathrm{~d}$, $J=8.0 \mathrm{~Hz}, 3 \mathrm{H}), 6.88(\mathrm{~d}, J=8.4 \mathrm{~Hz}, 2 \mathrm{H}), 4.54(\mathrm{t}, J=5.0 \mathrm{~Hz}$, $1 \mathrm{H}), 4.04(\mathrm{t}, J=6.2 \mathrm{~Hz}, 2 \mathrm{H}), 3.60-3.49(\mathrm{~m}, 2 \mathrm{H}), 2.24(\mathrm{~s}, 3 \mathrm{H})$, 1.91-1.79 (m, 2H). ${ }^{13} \mathrm{C}-\mathrm{NMR}\left(75 \mathrm{MHz}, \mathrm{DMSO}-d_{6}\right) \delta: 179.1$, $160.2,148.3,130.4,128.6,114.5,65.1,57.7,32.5,14.3$. ESI-MS $\mathrm{m} / \mathrm{z}=268.4[\mathrm{M}+\mathrm{H}]^{+}$.

2 - (1 - (4 - Butoxy phenyl)ethylidene)hydrazine-1carbothioamide $(\mathbf{6 g})$

Solid product, yield $83 \%$, mp $166-167^{\circ} \mathrm{C} .{ }^{1} \mathrm{H}-\mathrm{NMR}$ $\left(300 \mathrm{MHz}, \mathrm{DMSO}-d_{6}\right) \delta: 10.09(\mathrm{~s}, 1 \mathrm{H}), 8.18(\mathrm{~s}, 1 \mathrm{H}), 7.86(\mathrm{~s}$, $1 \mathrm{H}), 7.84(\mathrm{~d}, J=8.8 \mathrm{~Hz}, 2 \mathrm{H}), 6.88(\mathrm{~d}, J=8.9 \mathrm{~Hz}, 2 \mathrm{H}), 3.98$ $(\mathrm{t}, J=6.4 \mathrm{~Hz}, 2 \mathrm{H}), 2.25(\mathrm{~s}, 3 \mathrm{H}), 1.76-1.61(\mathrm{~m}, 2 \mathrm{H}), 1.47-1.36$ $(\mathrm{m}, 2 \mathrm{H}), 0.92(\mathrm{t}, J=7.3 \mathrm{~Hz}, 3 \mathrm{H}) .{ }^{13} \mathrm{C}-\mathrm{NMR}(75 \mathrm{MHz}, \mathrm{DMSO}-$ $\left.d_{6}\right) \delta: 178.6,160.0,147.8,129.8,128.1,114.0,67.2,30.7,18.7$, 13.8, 13.7. ESI-MS $m / z=266.2[\mathrm{M}+\mathrm{H}]^{+}$. Anal. Calcd for $\mathrm{C}_{13} \mathrm{H}_{19} \mathrm{~N}_{3} \mathrm{OS}$ : C, 58.84; H, 7.22; N, 15.83. Found C, 59.06; H, $7.18 ; \mathrm{N}, 15.86$

2-(1-(4-iso-Butoxy phenyl)ethylidene)hydrazine-1carbothioamide $(\mathbf{6 h})$

Solid product, yield $86 \%$, mp $148-149^{\circ} \mathrm{C} .{ }^{1} \mathrm{H}-\mathrm{NMR}$ $\left(300 \mathrm{MHz}, \mathrm{DMSO}-d_{6}\right) \delta: 10.07(\mathrm{~s}, 1 \mathrm{H}), 8.17(\mathrm{~s}, 1 \mathrm{H}), 8.86(\mathrm{~s}$, $1 \mathrm{H}), 7.84(\mathrm{~d}, J=8.7 \mathrm{~Hz}, 2 \mathrm{H}), 6.89(\mathrm{~d}, J=8.8 \mathrm{~Hz}, 2 \mathrm{H}), 3.76$ (d, $J=6.5 \mathrm{~Hz}, 2 \mathrm{H}), 2.25$ (s, 3H), 2.07-1.94 (m, 1H), 0.98 $(\mathrm{d}, J=6.7 \mathrm{~Hz}, 6 \mathrm{H}) .{ }^{13} \mathrm{C}-\mathrm{NMR}\left(75 \mathrm{MHz}, \mathrm{DMSO}-d_{6}\right) \delta: 179.3$, $160.4,148.5,130.6,128.7,114.8,74.6,28.5,19.9$, 14.7. ESI-MS $m / z=266.2[\mathrm{M}+\mathrm{H}]^{+}$. Anal. Calcd for $\mathrm{C}_{13} \mathrm{H}_{19} \mathrm{~N}_{3} \mathrm{OS}$ : C, 58.84; H, 7.22; N, 15.83. Found C, 59.14; H, 7.15; N, 15.84 .

2-(1-(4-(4-Chlorobutoxy)phenyl)ethylidene)hydrazine-1carbothioamide $(\mathbf{6 i})$

Solid product, yield $83 \%$, mp $159-160{ }^{\circ} \mathrm{C} .{ }^{1} \mathrm{H}-\mathrm{NMR}$ $\left(300 \mathrm{MHz}, \mathrm{DMSO}-d_{6}\right) \delta: 10.15(\mathrm{~s}, 1 \mathrm{H}), 8.26(\mathrm{~s}, 1 \mathrm{H}), 7.91(\mathrm{~s}$, $1 \mathrm{H}), 7.43$ (d, $J=8.9 \mathrm{~Hz}, 2 \mathrm{H}), 7.26$ (t, $J=7.9 \mathrm{~Hz}, 1 \mathrm{H}), 6.93$ (d, $J=8.1 \mathrm{~Hz}, 1 \mathrm{H}), 4.04(\mathrm{t}, J=5.3 \mathrm{~Hz}, 2 \mathrm{H}), 3.70$ (t, $J=5.7 \mathrm{~Hz}$, $2 \mathrm{H}), 2.27(\mathrm{~s}, 3 \mathrm{H}), 1.99-1.75(\mathrm{~m}, 4 \mathrm{H}),{ }^{13} \mathrm{C}-\mathrm{NMR} \quad(75 \mathrm{MHz}$, DMSO- $\left.d_{6}\right) \delta: 178.8,158.5,147.9,139.1,129.2,119.1,115.4$, $112.4 ， 66.7 ， 45.2 ， 28.9, \quad 26.1 ， 14.2$. ESI-MS $m / z=300.2$ $[\mathrm{M}+\mathrm{H}]^{+}$. Anal. Calcd for $\mathrm{C}_{13} \mathrm{H}_{18} \mathrm{ClN}_{3} \mathrm{OS}$ : C, 52.08; H, 6.05; N, 14.02. Found C, 52.47; H, 6.09; N, 13.69.

2 - (1 - (4 - Pentoxy phenyl)ethylidene)hydrazine-1carbothioamide $(\mathbf{6 j})$

Solid product, yield $82 \%$, mp $122-123^{\circ} \mathrm{C} .{ }^{1} \mathrm{H}-\mathrm{NMR}$ $\left(300 \mathrm{MHz}, \mathrm{DMSO}-d_{6}\right) \delta: 10.18(\mathrm{~s}, 1 \mathrm{H}), 8.27(\mathrm{~s}, 1 \mathrm{H}), 7.89(\mathrm{~d}$, $J=8.9 \mathrm{~Hz}, 3 \mathrm{H}), 6.91(\mathrm{~d}, J=9.0 \mathrm{~Hz}, 2 \mathrm{H}), 3.96(\mathrm{t}, J=6.5 \mathrm{~Hz}$, $2 \mathrm{H}), 2.29(\mathrm{~s}, 3 \mathrm{H}), 1.77-1.63(\mathrm{~m}, 2 \mathrm{H}), 1.45-1.25(\mathrm{~m}, 4 \mathrm{H})$, 0.89 (t, $J=7.0 \mathrm{~Hz}, 3 \mathrm{H}) .{ }^{13} \mathrm{C}-\mathrm{NMR}\left(75 \mathrm{MHz}, \mathrm{DMSO}-d_{6}\right) \quad \delta$ : $176.2,157.3,145.4,127.5,125.7,111.6,65.1,26.0,25.3,19.6$, 11.5, 11.5. ESI-MS $m / z=280.3[\mathrm{M}+\mathrm{H}]^{+}$. Anal. Calcd for $\mathrm{C}_{14} \mathrm{H}_{21} \mathrm{~N}_{3} \mathrm{OS}$ : C, 60.18; H, 7.58; N, 15.04. Found C, 60.46; H, $7.60 ; \mathrm{N}, 14.92$. 
2 - (1 - (4 - Hexoxyphenyl)ethylidene)hydrazine - 1 carbothioamide (6k)

Solid product, yield $82 \%$, mp $140-141^{\circ} \mathrm{C} .{ }^{1} \mathrm{H}-\mathrm{NMR}$ $\left(300 \mathrm{MHz}, \mathrm{DMSO}-d_{6}\right) \delta: 10.15(\mathrm{~s}, 1 \mathrm{H}), 8.24(\mathrm{~s}, 1 \mathrm{H}), 7.88(\mathrm{~d}$, $J=8.8 \mathrm{~Hz}, 3 \mathrm{H}), 6.91(\mathrm{~d}, J=8.9 \mathrm{~Hz}, 2 \mathrm{H}), 3.97(\mathrm{t}, J=6.4 \mathrm{~Hz}$, $2 \mathrm{H}), 2.27$ (s, 3H), 1.78-1.63 (m, 2H), 1.49-1.23 (m, 7H), 0.87 $(\mathrm{t}, J=6.7 \mathrm{~Hz}, 3 \mathrm{H}),{ }^{13} \mathrm{C}-\mathrm{NMR}\left(75 \mathrm{MHz}, \mathrm{DMSO}-d_{6}\right) \delta: 178.6$, $159.6,147.7,129.8,128.1,113.9,67.5,31.0,28.6,25.2,22.1$, 13.9, 13.8. ESI-MS $m / z=294.3[\mathrm{M}+\mathrm{H}]^{+}$.

2-(1-(4-Cyclohexyloxy phenyl)ethylidene)hydrazine-1carbothioamide (6I)

Solid product, yield $88 \%$, mp $160-161^{\circ} \mathrm{C} .{ }^{1} \mathrm{H}-\mathrm{NMR}$ $\left(300 \mathrm{MHz}, \mathrm{DMSO}-d_{6}\right) \delta: 10.09(\mathrm{~s}, 1 \mathrm{H}), 8.18(\mathrm{~s}, 1 \mathrm{H}), 7.84(\mathrm{~d}$, $J=8.3 \mathrm{~Hz}, 3 \mathrm{H}), 6.91(\mathrm{~d}, J=8.6 \mathrm{~Hz}, 2 \mathrm{H}), 4.40(\mathrm{~s}, 1 \mathrm{H}), 2.28(\mathrm{~s}$, $3 \mathrm{H}), 2.00-1.85(\mathrm{~m}, 2 \mathrm{H}), 1.80-1.65(\mathrm{~m}, 2 \mathrm{H}), 1.60-1.22(\mathrm{~m}, 6 \mathrm{H})$. ${ }^{13} \mathrm{C}-\mathrm{NMR}\left(75 \mathrm{MHz}, \mathrm{DMSO}-d_{6}\right) \delta$ : 179.3, 159.0, 148.6, 130.5, $128.8,116.0,75.1,32.1,26.0,23.9,14.7$. ESI-MS $m / z=292.3$ $[\mathrm{M}+\mathrm{H}]^{+}$.

2-(1-(4-Heptyloxy phenyl)ethylidene)hydrazine-1carbothioamide $(6 \mathbf{m})$

Solid product, yield 79\%, mp $126-127^{\circ} \mathrm{C} .{ }^{1} \mathrm{H}-\mathrm{NMR}$ $\left(300 \mathrm{MHz}, \mathrm{DMSO}-d_{6}\right) \delta: 10.16(\mathrm{~s}, 1 \mathrm{H}), 8.25(\mathrm{~s}, 1 \mathrm{H}), 7.88(\mathrm{~d}$, $J=8.9 \mathrm{~Hz}, 3 \mathrm{H}), 6.90(\mathrm{~d}, J=9.0 \mathrm{~Hz}, 2 \mathrm{H}), 3.97(\mathrm{t}, J=6.4 \mathrm{~Hz}$, $2 \mathrm{H}), 2.27(\mathrm{~s}, 3 \mathrm{H}), 1.77-1.63(\mathrm{~m}, 2 \mathrm{H}), 1.46-1.18(\mathrm{~m}, 8 \mathrm{H})$, $0.87(\mathrm{t}, J=9.1 \mathrm{~Hz}, 3 \mathrm{H}) .{ }^{13} \mathrm{C}-\mathrm{NMR}\left(75 \mathrm{MHz}, \mathrm{DMSO}-d_{6}\right) \quad \delta$ : $178.58,159.63,147.71,129.82,128.04,113.93,67.45,31.23$, $28.64,28.47,25.47,22.05,13.89,13.79$. ESI-MS $m / z=308.3$ $[\mathrm{M}+\mathrm{H}]^{+}$. Anal. Calcd for $\mathrm{C}_{16} \mathrm{H}_{25} \mathrm{~N}_{3} \mathrm{OS}: \mathrm{C}, 62.50 ; \mathrm{H}, 8.20 ; \mathrm{N}$, 13.67. FoundC, 62.43; H, 8.10; N, 13.48 .

2 - (1 - (4 - Octyloxy phenyl)ethylidene)hydrazine-1carbothioamide (6n)

Solid product, yield 77\%, mp $127-128^{\circ} \mathrm{C} .{ }^{1} \mathrm{H}-\mathrm{NMR}$ $\left(300 \mathrm{MHz}, \mathrm{DMSO}-d_{6}\right) \delta: 10.08(\mathrm{~s}, 1 \mathrm{H}), 8.18(\mathrm{~s}, 1 \mathrm{H}), 7.83(\mathrm{~d}$, $J=8.9 \mathrm{~Hz}, 3 \mathrm{H}), 6.87(\mathrm{~d}, J=8.9 \mathrm{~Hz}, 2 \mathrm{H}), 3.95(\mathrm{t}, J=6.4 \mathrm{~Hz}$, $2 \mathrm{H}), 2.25(\mathrm{~s}, 3 \mathrm{H}), 1.76-1.64(\mathrm{~m}, 2 \mathrm{H}), 1.39-1.25(\mathrm{~m}, 10 \mathrm{H}), 0.83$ $(\mathrm{d}, J=6.8 \mathrm{~Hz}, 3 \mathrm{H}) .{ }^{13} \mathrm{C}-\mathrm{NMR}\left(75 \mathrm{MHz}, \mathrm{DMSO}-d_{6}\right) \delta: 179.2$, $160.3,148.4,130.5,128.7,114.7,68.3,32.1,29.6,29.5,26.4$, 22.9, 14.8, 14.7. ESI-MS $m / z=322.4[\mathrm{M}+\mathrm{H}]^{+}$. Anal. Calcd for $\mathrm{C}_{17} \mathrm{H}_{27} \mathrm{~N}_{3} \mathrm{OS}$ : C, 63.51; H, 8.47; N, 13.07. Found C, 63.44; H, $8.38 ; \mathrm{N}, 12.95$

2 - (1 - (4 - Phenoxy phenyl)ethylidene)hydrazine-1carbothioamide (6o)

Solid product, yield $82 \%$, mp $171-172^{\circ} \mathrm{C} . \quad{ }^{1} \mathrm{H}-\mathrm{NMR}$ $\left(300 \mathrm{MHz}, \mathrm{DMSO}-d_{6}\right) \delta$ : $10.15(\mathrm{~s}, 1 \mathrm{H}), 8.22(\mathrm{~s}, 1 \mathrm{H}), 7.92$ $(\mathrm{d}, J=8.9 \mathrm{~Hz}, 2 \mathrm{H}), 7.88(\mathrm{~s}, 1 \mathrm{H}), 7.43-7.30(\mathrm{~m}, 2 \mathrm{H}), 7.13(\mathrm{t}$, $J=7.4 \mathrm{~Hz}, 1 \mathrm{H}), 7.03-6.98(\mathrm{~m}, 2 \mathrm{H}), 6.93(\mathrm{~d}, J=8.9 \mathrm{~Hz}, 2 \mathrm{H})$, $2.25(\mathrm{~s}, 3 \mathrm{H}) .{ }^{13} \mathrm{C}-\mathrm{NMR}\left(75 \mathrm{MHz}, \mathrm{DMSO}-d_{6}\right) \delta: 178.8,157.7$, $156.1,147.2,132.7,130.1,128.5,123.8,119.0,117.8,13.9$. ESIMS $m / z=286.4[\mathrm{M}+\mathrm{H}]^{+}$.

2-(1-(4-((4-Bromobenzyl)oxy)phenyl)ethylidene)hydrazine-1-carbothioamide (6p)

Solid product, yield $81 \%$, mp $197-198^{\circ} \mathrm{C} .{ }^{1} \mathrm{H}-\mathrm{NMR}$ $\left(300 \mathrm{MHz}, \mathrm{DMSO}-d_{6}\right) \delta: 10.08(\mathrm{~s}, 1 \mathrm{H}), 8.17(\mathrm{~s}, 1 \mathrm{H}), 7.86(\mathrm{~d}$, $J=8.8 \mathrm{~Hz}, 3 \mathrm{H}), 7.57$ (d, $J=8.3 \mathrm{~Hz}, 2 \mathrm{H}), 7.39$ (d, $J=8.4 \mathrm{~Hz}$, $2 \mathrm{H}), 6.96(\mathrm{~d}, J=8.9 \mathrm{~Hz}, 2 \mathrm{H}), 5.12(\mathrm{~s}, 2 \mathrm{H}), 2.24(\mathrm{~s}, 3 \mathrm{H})$. ${ }^{13} \mathrm{C}-\mathrm{NMR}\left(75 \mathrm{MHz}, \mathrm{DMSO}-d_{6}\right) \delta$ : 178.6, 159.0, 147.7, 136.4, 131.3, 130.4, 129.8, 128.13, 120.9, 114.4, 68.4, 13.8. ESI-MS $m / z=378.2[\mathrm{M}+\mathrm{H}]^{+}$. Anal. Calcd for $\mathrm{C}_{16} \mathrm{H}_{16} \mathrm{BrN}_{3} \mathrm{OS}: \mathrm{C}$, 50.80; H, 4.26; N, 11.11. Found C, 50.61; H, 4.33; N, 10.83 .
2-(1-(4-(3-Phenylpropoxy)phenyl)ethylidene)hydrazine-1carbothioamide (6q)

Solid product, yield $85 \%$, mp $148-149^{\circ} \mathrm{C} .{ }^{1} \mathrm{H}-\mathrm{NMR}$ $\left(300 \mathrm{MHz}, \mathrm{DMSO}-d_{6}\right) \delta: 10.10(\mathrm{~s}, 1 \mathrm{H}), 8.19$ (s, 1H), 7.85 (d, $J=8.6 \mathrm{~Hz}, 3 \mathrm{H}), 7.31-7.11(\mathrm{~m}, 5 \mathrm{H}), 6.89(\mathrm{~d}, J=8.8 \mathrm{~Hz}, 2 \mathrm{H})$, $3.97(\mathrm{t}, J=6.2 \mathrm{~Hz}, 2 \mathrm{H}), 2.73(\mathrm{t}, J=7.6 \mathrm{~Hz}, 2 \mathrm{H}), 2.25(\mathrm{~s}, 3 \mathrm{H})$, $2.06-1.95(\mathrm{~m}, 2 \mathrm{H}) .{ }^{13} \mathrm{C}-\mathrm{NMR}\left(75 \mathrm{MHz}, \mathrm{DMSO}-d_{6}\right) \delta: 179.3$, $160.2,148.5,142.0,130.7,129.0,128.8,126.5,114.8,67.6$, 32.3, 31.2, 14.7. ESI-MS $m / z=328.3[\mathrm{M}+\mathrm{H}]^{+}$. Anal. Calcd for $\mathrm{C}_{18} \mathrm{H}_{21} \mathrm{~N}_{3} \mathrm{OS}: \mathrm{C}$, 66.02; H, 6.46; N, 12.83. Found C, 66.13; H, $6.47 ; \mathrm{N}, 12.78$.

Ethyl 2-(4-(1-(2-Carbamothioylhydrazono)ethyl)phenoxy)acetate (6r)

Solid product, yield $81 \%$, mp $156-157^{\circ} \mathrm{C} . \quad{ }^{1} \mathrm{H}-\mathrm{NMR}$ $\left(300 \mathrm{MHz}, \mathrm{DMSO}-d_{6}\right) \delta: 10.09(\mathrm{~s}, 1 \mathrm{H}), 8.18(\mathrm{~s}, 1 \mathrm{H}), 7.85(\mathrm{~d}$, $J=8.7 \mathrm{~Hz}, 3 \mathrm{H}), 6.89$ (d, $J=8.8 \mathrm{~Hz}, 2 \mathrm{H}), 4.81(\mathrm{~s}, 2 \mathrm{H}), 4.15$ (q, $J=7.1 \mathrm{~Hz}, 2 \mathrm{H}), 2.25$ (s, 3H), $1.21(\mathrm{t}, J=7.1 \mathrm{~Hz}, 3 \mathrm{H}) .{ }^{13} \mathrm{C}-\mathrm{NMR}$ $\left(75 \mathrm{MHz}, \mathrm{DMSO}-d_{6}\right) \delta: 179.3,169.1,159.1,148.3,131.4,128.7$, $114.8,65.5,61.5,14.9$, 14.7. ESI-MS $m / z=296.2[\mathrm{M}+\mathrm{H}]^{+}$. Anal. Calcd for $\mathrm{C}_{13} \mathrm{H}_{17} \mathrm{~N}_{3} \mathrm{O}_{3} \mathrm{~S}: \mathrm{C}, 52.86 ; \mathrm{H}, 5.80 ; \mathrm{N}, 14.23$. Found C, 52.74; H, 5.67; N, 14.19.

2-(4-(1-(2-Carbamothioylhydrazono)ethyl)phenoxy)acetic Acid (6s)

Solid product, yield $91 \%$, mp $197-198^{\circ} \mathrm{C} . \quad{ }^{1} \mathrm{H}-\mathrm{NMR}$ $\left(300 \mathrm{MHz}, \mathrm{DMSO}-d_{6}\right) \delta: 12.97(\mathrm{~s}, 1 \mathrm{H}), 10.10(\mathrm{~s}, 1 \mathrm{H}), 8.18$ (s, $1 \mathrm{H}), 7.85(\mathrm{~d}, J=8.6 \mathrm{~Hz}, 2 \mathrm{H}), 6.87(\mathrm{~d}, J=8.7 \mathrm{~Hz}, 2 \mathrm{H}), 4.70$ $(\mathrm{s}, 2 \mathrm{H}), 2.25$ (s, 3H). ${ }^{13} \mathrm{C}-\mathrm{NMR}\left(75 \mathrm{MHz}, \mathrm{DMSO}-d_{6}\right) \delta: 179.3$, $170.6,159.3,148.4,131.2,128.7,114.8,65.3,14.7$. ESI-MS $m / z=266.1[\mathrm{M}-\mathrm{H}]^{-}$.

Ethyl 4-(4-(1-(2-Carbamothioylhydrazono)ethyl)phenoxy)butanoate (6t)

Solid product, yield $71 \%$, mp $129-130^{\circ} \mathrm{C} .{ }^{1} \mathrm{H}-\mathrm{NMR}$ $\left(300 \mathrm{MHz}, \mathrm{DMSO}-d_{6}\right) \delta: 10.09(\mathrm{~s}, 1 \mathrm{H}), 8.18(\mathrm{~s}, 1 \mathrm{H}), 7.84(\mathrm{~d}$, $J=8.5 \mathrm{~Hz}, 3 \mathrm{H}), 6.88(\mathrm{~d}, J=8.6 \mathrm{~Hz}, 2 \mathrm{H}), 4.11-3.94(\mathrm{~m}, 4 \mathrm{H})$, $2.44(\mathrm{t}, J=7.2 \mathrm{~Hz}, 2 \mathrm{H}), 2.25(\mathrm{~s}, 3 \mathrm{H}), 2.04-1.89(\mathrm{~m}, 2 \mathrm{H}), 1.16$ $(\mathrm{t}, J=7.1 \mathrm{~Hz}, 3 \mathrm{H}) .{ }^{13} \mathrm{C}-\mathrm{NMR}\left(75 \mathrm{MHz}, \mathrm{DMSO}-d_{6}\right) \delta: 179.2$, 173.1, 160.0, 148.4, 130.7, 128.8, 114.7, 67.3, 60.6, 31.0, 25.0, 15.0, 14.7. ESI-MS $m / z=324.3[\mathrm{M}+\mathrm{H}]^{+}$.

4-(4-(1-(2-Carbamothioylhydrazono)ethyl)phenoxy)butanoic Acid (6u)

Solid product, yield $89 \%, \mathrm{mp} \quad 197-198^{\circ} \mathrm{C} .{ }^{1} \mathrm{H}-\mathrm{NMR}$ $\left(300 \mathrm{MHz}, \mathrm{DMSO}-d_{6}\right) \delta$ : $12.12(\mathrm{~s}, 1 \mathrm{H}), 10.08(\mathrm{~s}, 1 \mathrm{H}), 8.17$ (s, 1H), $7.84(\mathrm{~d}, J=8.3 \mathrm{~Hz}, 2 \mathrm{H}), 6.89(\mathrm{~d}, J=8.5 \mathrm{~Hz}, 2 \mathrm{H})$, $4.00(\mathrm{t}, J=6.2 \mathrm{~Hz}, 2 \mathrm{H}), 2.38(\mathrm{t}, J=7.2 \mathrm{~Hz}, 2 \mathrm{H}), 2.25(\mathrm{~s}, 3 \mathrm{H})$, $2.02-1.85(\mathrm{~m}, 2 \mathrm{H}) .{ }^{13} \mathrm{C}-\mathrm{NMR}\left(75 \mathrm{MHz}, \mathrm{DMSO}-d_{6}\right) \delta: 179.2$, 174.6, 160.1, 148.5, 130.7, 128.8, 114.7, 67.4, 30.9, 25.0, 14.7. ESI-MS $m / z=294.1[\mathrm{M}-\mathrm{H}]^{-}$.

2-(1-(4-(2,2-Diethoxyethoxy)phenyl)ethylidene)hydrazine-1carbothioamide (6v)

Solid product, yield $75 \%$, mp $136-137^{\circ} \mathrm{C} .{ }^{1} \mathrm{H}-\mathrm{NMR}$ $\left(300 \mathrm{MHz}, \mathrm{DMSO}-d_{6}\right) \delta: 10.09(\mathrm{~s}, 1 \mathrm{H}), 8.18(\mathrm{~s}, 1 \mathrm{H}), 7.85(\mathrm{~d}$, $J=8.9 \mathrm{~Hz}, 3 \mathrm{H}), 6.92(\mathrm{~d}, J=9.0 \mathrm{~Hz}, 2 \mathrm{H}), 4.79(\mathrm{t}, J=5.1 \mathrm{~Hz}$, $1 \mathrm{H}), 3.98(\mathrm{~d}, J=5.1 \mathrm{~Hz}, 2 \mathrm{H}), 3.75-3.47(\mathrm{~m}, 4 \mathrm{H}), 2.25(\mathrm{~s}$, $3 \mathrm{H}), 1.14(\mathrm{t}, J=7.0 \mathrm{~Hz}, 6 \mathrm{H}) .{ }^{13} \mathrm{C}-\mathrm{NMR}\left(75 \mathrm{MHz}, \mathrm{DMSO}-d_{6}\right)$ $\delta: 179.2,159.8,148.3,131.0,128.8,114.85,100.6,68.9,62.7$, 16.2, 14.7. ESI-MS $m / z=326.3[\mathrm{M}+\mathrm{H}]^{+}$. Anal. Calcd for $\mathrm{C}_{15} \mathrm{H}_{23} \mathrm{~N}_{3} \mathrm{O}_{3} \mathrm{~S}$ : C, 55.36; H, 7.12; N, 12.91. Found C, 55.66; H, $7.14 ; \mathrm{N}, 13.24$.

2-(4-(3 -Hydroxy propoxy)benzylidene)hydrazine-1carbothioamide (11)

Yellowish solid product, yield $85 \%, \mathrm{mp} \quad 172-173^{\circ} \mathrm{C}$. 
${ }^{1} \mathrm{H}-\mathrm{NMR}\left(300 \mathrm{MHz}, \mathrm{DMSO}-d_{6}\right) \delta: 11.34(\mathrm{~s}, 1 \mathrm{H}), 8.14(\mathrm{~s}, 1 \mathrm{H})$, $8.02(\mathrm{~s}, 1 \mathrm{H}), 7.94(\mathrm{~s}, 1 \mathrm{H}), 7.74(\mathrm{~d}, J=8.8 \mathrm{~Hz}, 1 \mathrm{H}), 6.96(\mathrm{~d}$, $J=8.8 \mathrm{~Hz}, 1 \mathrm{H}), 4.60(\mathrm{t}, J=5.1 \mathrm{~Hz}, 1 \mathrm{H}), 4.08(\mathrm{t}, J=6.4 \mathrm{~Hz}$, $2 \mathrm{H}), 3.58(\mathrm{t}, J=6.1 \mathrm{~Hz}, 2 \mathrm{H}), 1.88-1.91(\mathrm{~m}, 2 \mathrm{H}) .{ }^{13} \mathrm{C}-\mathrm{NMR}$ $\left(75 \mathrm{MHz}, \mathrm{DMSO}-d_{6}\right) \delta: 177.5,160.1,142.3,128.9,126.52$, 114.5, 64.7, 57.2, 32.0. ESI-MS $\mathrm{m} / z=254.3[\mathrm{M}+1]^{+}$. Anal. Calcd for $\mathrm{C}_{11} \mathrm{H}_{15} \mathrm{~N}_{3} \mathrm{O}_{2} \mathrm{~S}$ : C, 52.16; H, 5.97. Found C, 52.30; H, 6.01 .

2-(3-Ethyoxybenzylidene)hydrazine-1-carbothioamide (12a)

Solid product, yield 92\%, mp $165-166^{\circ} \mathrm{C} .{ }^{1} \mathrm{H}-\mathrm{NMR}$ $\left(300 \mathrm{MHz}, \mathrm{DMSO}-d_{6}\right) \delta$ : 11.44 (s, $\left.1 \mathrm{H}\right), 8.27$ (d, $J=19.3 \mathrm{~Hz}$, $1 \mathrm{H}), 8.09$ (s, 1H), 8.03 (s, 1H), $7.45(\mathrm{~s}, 1 \mathrm{H}), 7.38-7.17(\mathrm{~m}, 2 \mathrm{H})$, $7.02-6.90(\mathrm{~m}, 1 \mathrm{H}), 4.07(\mathrm{q}, J=7.0 \mathrm{~Hz}, 2 \mathrm{H}), 1.41-1.26(\mathrm{~m}, 3 \mathrm{H})$. ${ }^{13} \mathrm{C}-\mathrm{NMR}\left(75 \mathrm{MHz}, \mathrm{DMSO}-d_{6}\right) \delta: 177.9,158.8,142.2,135.5$, 129.7, 120.5, 116.6, 111.4, 63.1, 14.6. ESI-MS $m / z=224.2$ $[\mathrm{M}+1]^{+}$.

2-(3-Propoxybenzylidene)hydrazine-1-carbothioamide (12b)

Solid product, yield $89 \%$. mp $161-162^{\circ} \mathrm{C} .{ }^{1} \mathrm{H}-\mathrm{NMR}$ $\left(300 \mathrm{MHz}, \mathrm{DMSO}-d_{6}\right) \delta: 11.42(\mathrm{~s}, 1 \mathrm{H}), 8.21(\mathrm{~s}, 1 \mathrm{H}), 8.08(\mathrm{~s}$, $1 \mathrm{H}), 8.01(\mathrm{~s}, 1 \mathrm{H}), 7.44(\mathrm{~s}, 1 \mathrm{H}), 7.34-7.20(\mathrm{~m}, 2 \mathrm{H}), 6.99-6.92$ $(\mathrm{m}, 1 \mathrm{H}), 3.97(\mathrm{t}, J=6.5 \mathrm{~Hz}, 2 \mathrm{H}), 1.81-1.65(\mathrm{~m}, 2 \mathrm{H}), 0.99(\mathrm{t}$, $J=7.4 \mathrm{~Hz}, 3 \mathrm{H}) .{ }^{13} \mathrm{C}-\mathrm{NMR}\left(75 \mathrm{MHz}, \mathrm{DMSO}-d_{6}\right) \delta: 177.9,159.0$, $142.2,135.5,129.7,120.5,116.6,111.5,69.0,22.0,10.4$. ESIMS $m / z=238.2[\mathrm{M}+1]^{+}$.

2-(3-Butoxybenzylidene)hydrazine-1-carbothioamide (12c)

Solid product, yield $86 \%$, mp $151-152^{\circ} \mathrm{C} .{ }^{1} \mathrm{H}-\mathrm{NMR}$ $\left(300 \mathrm{MHz}, \mathrm{DMSO}-d_{6}\right) \delta: 11.35(\mathrm{~s}, 1 \mathrm{H}), 8.18(\mathrm{~s}, 1 \mathrm{H}), 8.04$ (s, 1H), $7.97(\mathrm{~s}, 1 \mathrm{H}), 7.41(\mathrm{~s}, 1 \mathrm{H}), 7.3-7.17(\mathrm{~m}, 2 \mathrm{H}), 6.92(\mathrm{~d}$, $J=9.1 \mathrm{~Hz}, 1 \mathrm{H}), 3.99$ (t, $J=6.4 \mathrm{~Hz}, 2 \mathrm{H}), 1.76-1.61$ (m, 2H), $1.51-1.36(\mathrm{~m}, 2 \mathrm{H}), 0.93(\mathrm{t}, J=7.3 \mathrm{~Hz}, 3 \mathrm{H}) .{ }^{13} \mathrm{C}-\mathrm{NMR}(75 \mathrm{MHz}$, DMSO- $\left.d_{6}\right) \delta: 177.9,159.0,142.2,135.5,129.6,120.5,116.6$, 111.5, 67.2, 30.8, 18.7, 13.7. Anal. Calcd for $\mathrm{C}_{12} \mathrm{H}_{17} \mathrm{~N}_{3} \mathrm{OS}$ : C, 57.34; H, 6.82. Found C, 57.30; H, 6.86.

Assay of Inhibitory Activities of Target Compounds The inhibition of target compounds on the diphenolase activity of mushroom tyrosinase was investigated by the reported procedure $^{45-53)}$ with some slight modifications. Briefly, all the synthesized compounds were screened for the diphenolase inhibitory activity of tyrosinase using L-DOPA as substrate. Thiosemicarbazide, kojic acid (used as a control) and all the target compounds were dissolved in DMSO and their final concentration in DMSO was $2.0 \%$. Phosphate buffer, $\mathrm{pH}$ 6.8, was used to dilute the DMSO stock solution of test compounds. Thirty units of tyrosinase $(0.5 \mathrm{mg} / \mathrm{mL})$ was first pre-incubated with the samples, in $50 \mathrm{mM}$ phosphate buffer, for $10 \mathrm{~min}$ at $25^{\circ} \mathrm{C}, \mathrm{L}$-DOPA solution $(0.5 \mathrm{mM})$ was added to the mixture and the enzyme reaction was monitored by measuring the change in absorbance at $475 \mathrm{~nm}$ of formation of DOPAchrome for $1 \mathrm{~min}$. The measurement was completed in triplicate for each concentration and averaged before further calculation. $\mathrm{IC}_{50}$ value was determined by interpolation of the dose-response curves. The assay of inhibition mechanism and inhibition types of selected compounds $\mathbf{5 a}$ and $\mathbf{6 a}$ on mushroom tyrosinase was finished as the reported protocol. ${ }^{45-53)}$

Assay of Cytotoxicity of Selected Compounds 5a, 6e, 6g and 6t to 293T Cell Line The assay of cytotoxicity of selected compounds to the 293T cell line was finished as the generally reported protocol. ${ }^{65-70)}$ Briefly, the $293 \mathrm{~T}$ cell suspension was prepared and $100 \mu \mathrm{L}$ of the suspension was injected in each tube placed in 96-hole culture plate, and the culture plate was pre-cultured in the incubator for $24 \mathrm{~h}$ $\left(37^{\circ} \mathrm{C}, 5 \% \mathrm{CO}_{2}\right) ; 10 \mu \mathrm{L}$ of different-concentration solution of 5a was added to each cell line tube and the final concentration of 5a was respectively kept in 31.25, 62.5, 125, 250, 500, $1000 \mu \mathrm{mol} / \mathrm{L}$; The culture plate was incubated for $24 \mathrm{~h}$ in the incubator, then $10 \mu \mathrm{L}$ of CCK-8 solution was added into each tube in 96-hole plate; After the culture plate was incubated for $4 \mathrm{~h}$ in the incubator, the absorbance of the mixture in each tube at $450 \mathrm{~nm}$ was determined using micro-plate reader.

The cell line tube to which compound 5a was not injected was used as reference and the cell-proliferation number of this cell line was assumed " 1. " At this time the cell proliferation number for each cell line tube was determined as 1.012, 1.086, $1.086,1.027,1.119,1.014$. With the same method, we also determined the cytotoxicities of compounds $\mathbf{6 e}, \mathbf{6 g}$ and $\mathbf{6 t}$ to $293 \mathrm{~T}$ cell line.

Acknowledgments We thank the GDAS' Project of Science and Technology Development (2018GDASCX-1014 and 2018GDASCX-0807), the Project of Tianhe District, Guangzhou for Innovation and Entrepreneurship Leading Talents, and the Project of Foshan Science and Technology Innovation for financial support of this study.

Conflict of Interest The authors declare no conflict of interest.

\begin{tabular}{|c|c|}
\hline & es \\
\hline 1) & Salomon E. I., Sundaram I \\
\hline & $2563-2605$ (1996). \\
\hline 2) & Shiino M., Watanabe Y., Umezawa K., Bioorg. Med. Chem., 90, \\
\hline & $1233-1240(2001)$. \\
\hline 3) & Huang X. H., Chen Q. X., Wang Q., Song K. K., Wang J., Sha L., \\
\hline & Guan X. J., Food Chem., 94, 1-6 (2006). \\
\hline 4) & Sánchez-Ferrer A., Rodríguez-López J. N., García-Cánovas F. \\
\hline & García-Garmona F., Biochim. Biophys. Acta, 1247, 1-11 (1995). \\
\hline 5) & Chen Q. X., Liu X. D., Huang H., Biochem. (Moscow), 68, 644-649 \\
\hline & (2003). \\
\hline 6) & Decker H., Tuczek F., Trends Biochem. Sci., 25, 392-397 (2000). \\
\hline 7) & Fenoll L. G., Peńalver M. J., Rodríguez-López J. N., Varón R., Gar- \\
\hline & cía-Cánovas F., Tudela J., Int. J. Biochem. Cell Biol., 36, 235-246 \\
\hline & (2004). \\
\hline 8) & Marusek C. M., Trobaugh N. M., Flurkey W. H., Inlow J. K., $J$. \\
\hline & Inorg. Biochem., 100, 108-123 (2006). \\
\hline 9) & Marumo K., Waite J. H., Biochim. Biophys. Acta, 872, 98-103 \\
\hline & (1986). \\
\hline & Sugumaran M., FEBS Lett., 293, 4-10 (1991). \\
\hline & Okombi S., Rival D., Bonnet S., Mariotte A. M., Perrier E., Bou- \\
\hline & mendjel A., Bioorg. Med. Chem. Lett., 16, 2252-2255 (2006). \\
\hline & Liu S. H., Pan I. H., Chu I. M., Biol. Pharm. Bull., 30, 1135-1139 \\
\hline & (2007). \\
\hline & Kubo I., Kinst-Hori I., J. Agric. Food Chem., 47, 4574-4578 (1999). \\
\hline & Nerya O., Musa R., Khatib S., Tamir S., Vaya J., Phytochemistry, \\
\hline & 65, 1389-1395 (2004). \\
\hline & Shi Y., Chen Q. X., Wang Q., Song K. K., Qiu L., Food Chem., \\
\hline & 2005, 707-712 (2005). \\
\hline & Xu Y., Stokes A. H., Freeman W. M., Kumer S. C., Vogt B. A., \\
\hline & Vrana K. E., Brain Res. Mol. Brain Res., 45, 159-162 (1997). \\
\hline & Asanuma M., Miyazaki I., Ogawa N. J., Neurotox. Res., 5, 165-176 \\
\hline & (2003). \\
\hline & Pan T., Li X., Jankovic J., Int. J. Cancer, 128, 2251-2260 (2011). \\
\hline & Khan K. M., Maharvi G. M., Khan M. T. H., Shaikh A. J., Perveen \\
\hline & S., Begum S., Choudhary M. I., Bioorg. Med. Chem., 14, 344-351 \\
\hline & (2006). \\
\hline & Okombi S., Rival D., Bonnet S., Mariotte A. M., Perrier E., Bol \\
\hline
\end{tabular}


mendjel A., J. Med. Chem., 49, 329-333 (2006).

21) Khatib S., Nerya O., Musa R., Tamir S., Peter T., Vaya J., J. Med. Chem., 50, 2676-2681 (2007).

22) Seo S. Y., Sharma V. K., Sharma N., J. Agric. Food Chem., 51, 2837-2853 (2003).

23) Kim J., Uyama H., Cell. Mol. Life Sci., 62, 1707-1723 (2005).

24) Khan M. T. H., Pure Appl. Chem., 79, 2277-2295 (2007).

25) Likhitwitayawuid K., Curr. Sci., 94, 44-52 (2008).

26) Chang T. S., Int. J. Mol. Sci., 10, 2440-2475 (2009).

27) Loizzo M. R., Tundis R., Menichini F., Compr. Rev. Food SCI. Food Saf., 11, 378-398 (2012).

28) Khan M. T. H., Curr. Med. Chem., 19, 2262-2272 (2012).

29) Wang Y., Curtis-Long M. J., Lee B. W., Yuk H. J., Kim D. W., Tan X. F., Park K. H., Bioorg. Med. Chem., 22, 1115-1120 (2014).

30) Iwadate T., Kashiwakura Y., Masuoka N., Yamada Y., Nihei K. I., Bioorg. Med. Chem. Lett., 24, 122-125 (2014).

31) Hamidian H., Azizi S., Bioorg. Med. Chem., 23, 7089-7094 (2015).

32) Iwadate T., Nihei K. I., Bioorg. Med. Chem., 23, 6650-6658 (2015).

33) Choi J., Park S. J., Jee J. G., Eur. J. Med. Chem., 106, 157-166 (2015)

34) Liu J., Wu F., Chen C., Bioorg. Med. Chem. Lett., 25, 5142-5146 (2015).

35) Radhakrishnan S., Shimmon R., Conn C., Baker A., Bioorg. Med. Chem. Lett., 25, 5495-5499 (2015).

36) Xue C. B., Wang L., Luo W. C., Xie X. Y., Jiang L., Xiao T., Bioorg. Med. Chem., 15, 2006-2015 (2007).

37) Zhu Y. J., Song K. K., Li Z. C., Pan Z. Z., Guo Y. J., Zhou J. J., Wang Q., Liu B., Chen Q. X., J. Agric. Food Chem., 57, 5518-5523 (2009).

38) Lee K. C., Thanigaimalai P., Sharma V. K., Kim M. S., Roh E., Hwang B. Y., Kim Y., Jung S. H., Bioorg. Med. Chem. Lett., 20, 6794-6796 (2010).

39) Li Z. C., Chen L. H., Yu X. J., Hu Y. H., Song K. K., Zhou X. W.,

\section{Chen Q. X., J. Agric. Food Chem., 58, 12537-12540 (2010).}

40) Chen L. H., Hu Y. H., Song W., Song K. K., Liu X., Jia Y. L. Zhuang J. X., Chen Q. X., J. Agric. Food Chem., 60, 1542-1547 (2012).

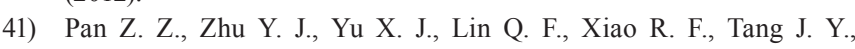
Chen Q. X., Liu B., J. Agric. Food Chem., 60, 10784-10788 (2012).

42) Yang M. H., Chen C. M., Hu Y. H., Zheng C. Y., Li Z. C., Ni L. L., Sun L., Chen Q. X., J. Biosci. Bioeng., 115, 514-517 (2013).

43) Zhu T. H., Cao S. W., Yu Y. Y., Int. J. Biol. Macromol., 62, 589-595 (2013).

44) Xie J., Dong H., Yu Y., Cao S., Food Chem., 190, 709-716 (2016).

45) Liu J. B., Yi W., Wan Y. Q., Ma L., Song H. C., Bioorg. Med. Chem., 16, 1096-1102 (2008).

46) Liu J. B., Cao R. H., Yi W., Ma C. M., Wan Y. Q., Zhou B. H., Ma

L., Song H. C., Eur. J. Med. Chem., 44, 1773-1778 (2009).

47) Yi W., Cao R. H., Wen H., Yan Q., Zhou B. H., Ma L., Song H. C., Bioorg. Med. Chem. Lett., 19, 6157-6160 (2009).

48) Yi W., Cao R. H., Chen Z. Y., Yu L., Ma L., Song H. C., Chem. Pharm. Bull., 57, 1273-1277 (2009).

49) Yi W., Cao R. H., Chen Z. Y., Yu L., Wen H., Yan Q., Ma L., Song H. C., Chem. Pharm. Bull., 58, 752-754 (2010).

50) Yi W., Dubois C., Yahiaoui S., Haudecoeur R., Belle C., Song H.
C., Hardré R., Réglier M., Boumendjel A., Eur. J. Med. Chem., 46, 4330-4335 (2011)

51) You A., Zhou J., Song S. C., Zhu G. X., Song H. C., Yi W., Bioorg. Med. Chem., 23, 924-931 (2015).

52) You A., Zhou J., Song S. C., Zhu G. X., Song H. C., Yi W., Eur. J. Med. Chem., 93, 255-262 (2015).

53) Song S. C., You A., Chen Z. Y., Zhu G. X., Wen H., Song H. C., Yi W., Eur. J. Med. Chem., 139, 815-825 (2017).

54) Thanigaimalai P., Hoang T. A., Lee K. C., Bang S. C., Sharma V. K., Yun C. Y., Roh E., Hwang B. Y., Kim Y., Jung S. H., Bioorg. Med. Chem. Lett., 20, 2991-2993 (2010).

55) Thanigaimalai P., Lee K. C., Sharma V. K., Roh E., Kim Y., Jung S. H., Bioorg. Med. Chem. Lett., 21, 3527-3530 (2011).

56) Buitrago E., Vuillamy A., Boumendjel A., Yi W., Gellon G., Hardré R., Philouze C., Serratrice G., Jamet H., Réglier M., Belle C., Inorg. Chem., 53, 12848-12858 (2014).

57) Matoba Y., Kumagai T., Yamamoto A., Yoshitsu H., Sugiyama M., J. Biochem., 281, 8981-8990 (2006).

58) Sendovski M., Kanteev M., Ben-Yosef V. S., Adir N., Fishman A., $J$. Mol. Biol., 405, 227-237 (2011).

59) Ismaya W. T., Rozeboom H. J., Weijn A., Mes J. J., Fusetti F., Wichers H. J., Dijkstra B. W., Biochem., 50, 5477-5486 (2011).

60) Ikeda K., Masujima T., Suzuki K., Sugiyama M., Appl. Microbiol. Biotechnol., 45, 80-85 (1996).

61) Ikeda K., Masujima T., Sugiyama M., J. Biochem. (Tokyo), 120 , 1141-1145 (1996).

62) Klabunde T., Eicken C., Sacchettini J. C., Krebs B., Nat. Struct. Biol., 5, 1084-1090 (1998).

63) Kubo I., Kinst-Hori I., J. Agric. Food Chem., 46, 5338-5341 (1998).

64) Jimenez M., Chazarra S., Escribano J., Cabanes J., García-Carmona F., J. Agric. Food Chem., 49, 4060-4063 (2001).

65) Shi Y., Chen Q. X., Wang Q., Song K. K., Qiu L., Food Chem., 92. 707-712 (2005).

66) Klabunde T., Eicken C., Sacchettini J. C., Krebs B., Nat. Struct. Biol., 5, 1084-1090 (1998).

67) Gençer N., Demir D., Sonmez F., Kucukislamoglu M., Bioorg. Med. Chem., 20, 2811-2821 (2012).

68) Ramsden C. A., Riley P. A., Bioorg. Med. Chem., 22, 2388-2395 (2014).

69) Sang Y. L., Namhuk B., Tae-gyu N., J. Enzyme Inhib. Med. Chem., 31, 1-13 (2016).

70) Yi W., Wu X., Cao R., Song H., Ma L., Food Chem., 117, 381-386 (2009).

71) Fuda H., Javitt B. N., Mitamura K., Ikegawa S., Strott A. C., J. Lipid Res., 48, 1343-1352 (2007).

72) "Cell Counting Kit-8 Technical Manual (Revised February 27, 2009).": 〈www.dojindo.com〉, cited July 20th, 2014.

73) Dedieu S., Canron X., Rezvani H. R., Bouchecareilh M., Mazurier F., Sinisi R., Zanda M., Moenner M., Bikfalvi A., North S., BMC Med., 8, 1-14 (2010).

74) Wang P.-F., Wang Z.-F., Qiu H.-Y., Huang Y., Hu H.-M., Wang Z.-C., Zhu H.-L., ChemMedChem, 13, 2558-2566 (2018).

75) ChemBioDraw Ultra 11.0. PerkinElmer, Waltham, MA, U.S.A., 2013.: 〈http://www.cambridgesoft.com〉, cited on 21 November, 2013. 